Article

\title{
An Evaluation of the Three Pillars of Sustainability in Cities with High Airbnb Presence: A Case Study of the City of Madrid
}

\author{
Agustín Álvarez-Herranz ${ }^{1, *(D)}$ and Edith Macedo-Ruíz ${ }^{2}$ (D) \\ 1 Faculty of Social Sciences, University of Castilla-La Mancha, 16071 Cuenca, Spain \\ 2 Faculty of Economic and Business Sciences, Autonomous University of Madrid, 28049 Madrid, Spain; \\ edith.macedo@estudiante.uam.es \\ * Correspondence: agustin.alvarez@uclm.es
}

Citation: Álvarez-Herranz, A.;

Macedo-Ruíz, E. An Evaluation of the Three Pillars of Sustainability in Cities with High Airbnb Presence: A Case Study of the City of Madrid. Sustainability 2021, 13, 3220. https://doi.org/10.3390/su13063220

Academic Editor: Adam E. Frampton

Received: 21 January 2021

Accepted: 8 March 2021

Published: 15 March 2021

Publisher's Note: MDPI stays neutral with regard to jurisdictional claims in published maps and institutional affiliations.

Copyright: (c) 2021 by the authors. Licensee MDPI, Basel, Switzerland. This article is an open access article distributed under the terms and conditions of the Creative Commons Attribution (CC BY) license (https:// creativecommons.org/licenses/by/ $4.0 /)$.

\begin{abstract}
The recent proliferation of private tourist accommodations on what has been known as sharing economy has induced new models on urban tourism and on the use of traditional housing. Urban tourism pressure has caused many transformation processes with important impacts in neighborhoods with high tourist interest, which are shown in the evolution of certain urban sustainability indicators, such as those proposed by the UN-Habitat Agenda for Sustainable Cities in line with the principles of the Leipzig Charter on Sustainable European Cities. Due to the above, the objective of this work is to analyze the spatial distribution of Airbnb accommodations, and explore the factors associated with the situation of Airbnb rentals in relation to the indicators of urban sustainability of neighborhoods and variables related to the gentrification processes of neighborhoods in which there is crowding or overtourism, measured through the Global Tourist Stress Index. For this, a first-order spatial autoregressive panel (SAR) data model with fixed effects has been specified, the results of which provide us with information to understand how sustainability indicators in the neighborhoods of the city of Madrid in the time period 2015-2018, they would explain the location and number of Airbnb accommodations found there. Additionally, it allows us to observe the existence of a spillover effect from the central neighborhoods, with a high per capita income, to nearby neighborhoods with lower income due to the level of tourist crowding, which is a contribution to the scarce existing literature.
\end{abstract}

Keywords: sharing economy; sustainability; Airbnb; spatial panel data models

JEL Classification: C21; C23; Z32

\section{Introduction}

The growth of large-scale tourism has led to the emergence of new forms of shared accommodation based on the collaborative economy model. The sharing economy is mainly accessed through online marketplaces where peer-to-peer (P2P) digital platforms offer users the possibility of monetizing their idle resources through potential consumers online with [1-4]. In the field of tourist accommodation, one of the most important platforms is Airbnb. The company was launched in 2008 with the premise that both individuals and professionals could offer accommodation through its site. The platform is present in more than 30,000 cities and 190 countries around the world [5].

The rise of this new type of tourist accommodation has led to the need to specify and estimate models to determine the factors that explain the location of these tourist apartments. Thus, the main motivation that led to carrying out this research work is the need to know the effects of the tourist apartment boom on the urban sustainability of the neighborhoods of the large tourist cities, specifically the city of Madrid, and the relationship that Airbnb has with the problem of gentrification in the parts of the city where this platform has a greater presence. There are very few studies dedicated to studying 
Airbnb's relationship with urban sustainability, and/or studying the sociodemographic factors that determine the location of this type of accommodation.

Our study aims to add value to the subject by explaining and analyzing the evolution of residential neighborhoods in the city of Madrid through a series of urban sustainability indicators. To do this, and with the aim that this research can be replicated in other cities, urban sustainability indicators are included that emerge from the UN-Habitat agenda [6] for sustainable cities and from the Leipzig Charter [7] of sustainable European cities.

These indicators will compile the impacts that the problem of "overtourism" has had on Madrid neighborhoods and understanding on the location and number of Airbnb accommodations in each them. Although there are several definitions of overtourism, we chose the definition by Milano [8] and the Collins dictionary [9] as: "the excessive growth of visitors leading to overcrowding in areas where residents suffer the consequences of temporary and seasonal tourism peaks, causing them permanent changes to their lifestyles", established.

Studying the evolution of Airbnb has a significant limitation: a lack of official data. To date, there are no official reports on how many Airbnb rooms are on the market. The data used in this analysis comes from the Inside Airbnb web portal for the period 2015-2018, and creates a database with geographic information (longitude and latitude) on each rental lodging. To this database, we added a series of sustainability indicators, built with information from the Madrid City Council's Data Bank (Banco de Datos del Ayuntamiento de Madrid) and the Experimental Economic Atlas of the Spanish National Statistics Institute (Instituto Nacional de Estadística (INE)).

Finally, to analyze the relationship between the evolution of Airbnb and the city's sustainability, taking into account the geo-referenced spatial location, we used a firstorder spatial autoregressive (SAR) panel data model with fixed effects, following the methodology suggested by $[10,11]$, which represents a further contribution to previous literature, which has to date used only cross-sectional models.

The expected results in this research agree with [12-14], regarding the increase in living costs and environmental degradation in neighborhoods with problems of tourist saturation and gentrification. The residential neighborhoods of Madrid that have problems of tourist saturation will have negative effects on the pillars of urban sustainability and could be considered effects derived from overtourism, as indicated by various studies, including [15-17].

This study is structured as follows. First, Section 2 presents the literature review. It briefly describes the research on the phenomenon of Airbnb in cities, the importance of studying Airbnb from the perspective of sustainability, and the current state of this platform in Madrid. Section 3 describes the data used and the indicators for each pillar that defines urban sustainable development. Section 4 defines the econometric model used, accompanied by a brief literature review of the theoretical foundation of the spatial model. Sections 5 and 6 discuss the final results and conclusions, respectively. Finally, Section 7 contains Appendix A and Section 8 contains the bibliography.

\section{Literature Review}

Airbnb is a hosting company founded in 2008 and whose success is linked to the development of the sharing economy. However, although the company itself uses the label of a shared economy model, the reality is that Airbnb's significance lies in innovative rental practices [14-16,18,19].

Airbnb proposed a business model that focuses primarily on cost savings, access to home comforts, and more authentic experiences where tourists and hosts were connected for the first time $[20,21]$. Currently the company has more than 2 million properties on offer and a presence in more than 191 countries [20,22,23].

The boom of Airbnb and its impact on cities has raised interest in academia. The most relevant research has focused on the transformation of market mechanisms in those cities where Airbnb has a strong presence [24]; in house prices $[12,13,25,26]$; in the impact 
on the hotel industry [27-30]. In a smaller number of them, they have focused on the impacts of Airbnb on the administration and urban planning of cities [31-33], on spatial analysis [34-36], and on the factors that influence the distribution of Airbnb offers [37].

Airbnb introduced new tourism practices [37] that have generated new forms of short-term private rentals aimed at a new type of tourists [38] seeking experiences and interactions with the local population [39,40]. Additionally, Airbnb offers home-sharing that gives residents the ability to earn money by renting underused accommodation. The ease of offering houses and rooms through the platform explains why Airbnb rentals are more dispersed than traditional accommodations and are expanding into neighborhoods that traditionally do not receive tourists [20]. Zervas, Proserpio and Byers [30] point out that the success of Airbnb is that it can expand the rental offerings wherever there are existing buildings, because accommodation belongs to individuals, while hotels respond to urban policies and require time and investment to expand its offering.

In this line of research, it is necessary to study the relationship between the factors that influence the spatial distribution of Airbnb's offer as of a vision of sustainable urban development, overtourism, and carrying capacity of destination cities. According to the United Nations Environment Program and the World Tourism Organization, sustainable development represents "a process to meet the needs of the present without compromising the ability of future generations to meet their own needs" [41]. This vision can be explained using the three fundamental pillars of sustainability: economic, social and environmental. Economic sustainability is linked to the efficiency of companies' activities in the long term; social sustainability refers to providing equal opportunities, reducing discrimination and poverty, while environmental sustainability corresponds to an adequate management of scarce resources and the non-contamination of the environment. Sustainable tourism must take into account current and future economic, social and environmental impacts, considering the needs of visitors, industry, the environment and host communities [41,42].

Sustainable tourism means maintaining a tourist destination in an optimal state, where the benefits of the local community are sustained and the tourist experience and the conservation of resources are satisfied [43]. However, it is important to know all the consequences of tourism in tourist destinations, independently about Airbnb. Table 1 shows some researches that analyze the positive and negative effects of tourism.

Table 1. Effects of Tourism.

\begin{tabular}{|c|c|}
\hline Positive Effects of Tourism & Authors \\
\hline Improve the local economy & $\begin{array}{c}\text { Liu, Sheldon and Var (1987), Gursoy and Rutherford (2004), Perdue, Long } \\
\text { and Allen (1990). }\end{array}$ \\
\hline Improve income and local standard of living & Liu and Var (1986), Milman and Pizam (1988), McCool and Martin (1994). \\
\hline $\begin{array}{c}\text { Boost the creation of new businesses and investment } \\
\text { opportunities }\end{array}$ & Dyer, Gursoy, Sharma and Carter (2007), Kwan and McCartney (2005). \\
\hline $\begin{array}{c}\text { Enrich the fabric of the community while preserving } \\
\text { cultural values }\end{array}$ & Andereck, Valentine, Knopt and Vogt (2005), Stronza and Gordillo (2008). \\
\hline Generates more job opportunities & $\begin{array}{l}\text { Crompton and Sanderson (1990), Choi and Sirakaya (2005), Diedrich and } \\
\text { García-Buades (2009), Haley, Snait and Miller (2005), Williams and } \\
\text { Lawson (2001). }\end{array}$ \\
\hline Encourage recreation opportunities & Gursoy and Rutherford (2004), Haley (2005). \\
\hline Cultural activities & Brunt and Courtney (1999) \\
\hline $\begin{array}{l}\text { Improve the quality of security such as police } \\
\text { protection }\end{array}$ & Milma \&Pizam (1988), Lagonigro, Martori, Apparicio (2020). \\
\hline $\begin{array}{c}\text { It can make the local population more environmentally } \\
\text { conscious }\end{array}$ & Andereck (2005), Gursoy and Rutherford (2004), Huh and Vogt (2008). \\
\hline
\end{tabular}


Table 1. Cont.

\begin{tabular}{cc}
\hline Negative Effects of Tourism & Authors \\
\hline $\begin{array}{c}\text { Resident cost of living increases } \\
\text { The price of land and housing increases } \\
\text { Increases traffic congestion and the feeling of } \\
\text { overcrowding } \\
\text { Increase tension and crime }\end{array}$ & $\begin{array}{c}\text { Liu and Var (1986), Perdue, Long and Allen (1990), Woo, Kim and Uysal } \\
\text { (2015), Sheng and Tsui (2009). }\end{array}$ \\
$\begin{array}{c}\text { and tourists } \\
\text { Increases psychological tensions between residents }\end{array}$ & $\begin{array}{c}\text { Belisle and Hoy (1980), Tovar and Lockwood (2008). } \\
\text { Andereck (2005), Dyer (2007), Sheng and Tsui (2009). }\end{array}$ \\
$\begin{array}{c}\text { It generates pollution, garbage, and noise } \\
\text { Destroy cultural and historical resources } \\
\text { Causes inefficiency in urban planning and disorderly } \\
\text { land use }\end{array}$ & Andereck (2005), Balaban (2012), Sheng and Tsui (2009). \\
Andereck et al. (2005)
\end{tabular}

Source: self-elaboration.

The urban destinations have limited space, resources, and carrying capacity [44], and once a certain threshold is reached, the attractiveness and comfort of the destination may decrease for both residents and visitors [45].

The carrying capacity of the destination is the focus of sustainable development. Resources are limited, so there will always be a maximum number of tourists that a destination can support without causing irreversible damage to the social, economic and environmental structure. In terms of the previous definition, the maximum number of tourists that a city could support would be that which allows its sustainable urban development. Camagni [46], defined the term of sustainable urban development as that process of synergistic integration and co-evolution between the large subsystems that make up a city (economic, social, physical and environmental), which guarantees the local population a non-decreasing level of well-being in the long run.

Ainsley O'Reilly [47] was the first to speak of the carrying capacity of a tourist destination. The word capacity in its true sense should suggest the number of tourists that can be contained in a certain space. The World Tourism Organization [48] proposes the following definition of carrying capacity: "The maximum number of people who can visit a tourist destination at the same time, without causing destruction of the physical, economic, socio-cultural environment".

In addition to the fact that Airbnb is related to the saturation of the carrying capacity of many cities, it has also been responsible for substantially changing the morphology of the destinations where it is present [49]. Likewise, these types of rentals are responsible for the overtourism of urban centers that were already very touristy $[14,50,51]$ and the invasion and gentrification of neighborhoods [21,52-54].

In this way, the overtourism experienced by some cities is not a cause of the sudden increase in the number of tourists, but rather the increasing presence of these in the residential neighborhoods of the cities [55-57]. Thus, it is establishing a negative relationship between the evolution of the resident population of the neighborhoods and the increase in tourists and tourist accommodation $[58,59]$.

The conversion of a dwelling from residential use to tourist use implies the idea of the disappearance of a home, and therefore its displacement. The rapid decline in residential flats in tourist cities such as Barcelona has had to do with the reduction in the size of homes due to the progressive aging of the population and the residential emancipation of young adults, who often moved to other sectors of the city, coupled with the increase in demand for tourist flats [58].

On this way, excessive stress from tourism can affect the day-to-day community life of city residents $[33,34,60]$. Furthermore, the tourism can compromise the city's sustainability [61].

Therefore, excessive temporary accommodation saturation puts a tourism area in a decisive, critical, and highly uncertain situation, which can even be accompanied by symptoms of degradation/exhaustion [47]. If no action is taken, this can lead to the final 
stages of degeneration, with the consequent decline and even, if prolonged, decay of the destination. Visitors feel that there are a lot of tourists and residents (hosts) beginning to express their rejection of tourists (guests) (social carrying capacity). This leading us to the concepts of "overcrowding", "saturation" or "congestion" of a tourist destination or even more localized place such as neighborhoods. These concepts are pejorative descriptions that refer to the negative influence of tourism on the perceived quality of life of residents and/or visitor experiences.

In this context, measuring the saturation of temporary accommodation in urban tourism spaces requires the use of a set of urban density indicators, like the Global Indicator of Tourist Stress (ISGT), defined as the total number tourist accommodation beds and hotel accommodation offer that exists per square meter. This perspective brings the issue of tourist density closer to that of "overtourism." This is because tourist density is considered the main cause of overtourism and the most relevant indicator for its measurement. The union of touristification and overtourism leads us to the concept of tourist gentrification. This term was coined by Kevin Fox Gotham, based on Neil Smith's [62] gentrification term, to "highlight the role that public policy has in promoting both gentrification and tourism development; and the actions of large leisure companies (... ) in the remodeling of [places] into entertainment and consumption spaces." This way, the growth of tourism transforms residential spaces into activities and venues oriented towards consumption, causing the expulsion of residents and increasing the value of properties [49].

Touristification is closely related to the transformations beginning in the city, derived from gentrification $[63,64]$.

For Freytag and Bauder [65], touristification is not a unidimensional model of cause and effect, but is a complex and multidimensional concept that is reflected in the interaction of heterogeneous actors and scenarios. For them, touristification must be seen on several levels. At a first level, it is due to approach this phenomenon as a visible change in the built environment or its functional use, for example, in the spread of localized shops or tourist services. Secondly, touristification should be approached as an invisible, barely evident change in the use of existing infrastructure, such as the ongoing transformation of regular homes into Airbnb tourist apartments. Furthermore, at the third level, tourism must be viewed from a perspective based on human agency with a focus on tourism practices and actions.

The effects of Airbnb on the housing market and its correspondence with the gentrification of neighborhoods has already been extensively studied. However, few studies focus on the sociodemographic characteristics that affect the distribution patterns of this platform [66]. Dudas [66] conducted a socio-economic analysis of Airbnb in New York City and found that Airbnb tended to focus on those areas of the city with a high proportion of youth, a significant number of housing units, and a large number of interest points. The work of Zhang and Chen [67], for example, studies the relationship between Airbnb's supply in three North American cities and finds that there is a relationship with employment, income level, educational level, and the youth population.

Sarkar, Koohikamali and Pick [68] studied Airbnb hosts and observed an inverse effect between income and the number of children, but not related to education. Roelofsen [69] explored the socio-spatial impacts of Airbnb in Sofia, Bulgaria, where short-term rentals are concentrated in areas with high-income populations. In contrast, Quattrone [26] found a negative influence of revenue on Airbnb's offer in the City of London.

The appearance of Airbnb broadens the concept of tourist gentrification by incorporating a series of peculiar characteristics that were not previously present, giving rise to the term "Airbnbficacion" [70]. These characteristics include the following:

1. The emergence of Airbnb in certain neighborhoods of tourist cities represents the beginning of a process by which the residential rental housing market is reduced in favor of a tourist rental housing market, with the consequent potential difficulty of access to housing by residents who don't get into the sales market or inherit a home [71]. 
2. The increase in the price of residential rentals and purchase-sales, caused by the proliferation of tourism rental homes, originates a process of social displacement [21,56,58,72].

3. The rise in prices and the contraction of the real estate market, although may have no short-term effect on those tenants who have current rental contracts; in the long-term, when contracts expire, new prices may no longer be accessible to those tenants. This causes the expulsion of these residents from their neighborhoods.

4. The social fracture between neighbors as a consequence of the increase in income by those who can afford to allocate their home or part of it for tourist accommodation.

5. The transformation of residential spaces into commercial and leisure areas.

Considering the above, the following hypotheses are put forward:

Hypothesis 1 (H1). There is a relationship between gentrification due to a greater saturation of tourists and the increase in Airbnb accommodations in Madrid neighborhoods:

Hypothesis 1a (H1a). Positive relationship between the increase in the purchase price of homes and the number of Airbnb accommodations in each neighborhood.

Hypothesis $\mathbf{1 b} \mathbf{( H 1 b ) . ~ P o s i t i v e ~ r e l a t i o n s h i p ~ b e t w e e n ~ t h e ~ r e s i d e n t i a l ~ r e n t a l ~ p r i c e ~ a n d ~ t h e ~ n u m b e r ~}$ of Airbnb accommodations in each neighborhood.

Hypothesis 1c (H1c). Positive relationship between the average household income and the number of Airbnb accommodations in each neighborhood.

Hypothesis 1d (H1d). Positive relationship between the ISGT and the number of Airbnb accommodations in each neighborhood.

In addition to the problems associated with housing and gentrification, tourist cities face additional challenges in terms of prevention and waste management due to the seasonality of tourism and the waste it produces [73]. Kennedy [74] defined urban metabolism as "the sum total of the technical and socioeconomic processes that occur in cities, resulting in growth, production of energy, and elimination of waste." An analysis of urban metabolism involves the quantification of the inputs, outputs, and storage of energy, materials, nutrients, water, and waste of a city. In this way, it becomes a useful indicator for the management of planning in sustainable urban development, [74]: "For cities to take sustainability seriously, the collection of data on urban metabolism must become an activity main. Urban metabolism can be affected by different factors, one of the most important is the population density of cities" [75].

From the above, we can establish Hypothesis 2.

Hypothesis 2 (H2). There is a positive relationship between the deterioration of the urban metabolism caused by the increase in tourists.

Hypothesis 2a (H2a). Positive relationship between urban waste and number of Airbnb accommodations.

Hypothesis $\mathbf{2 b} \mathbf{b} \mathbf{H} \mathbf{2 b})$. Positive relationship between noise and number of Airbnb accommodations.

Hypothesis 2c (H2c). Positive relationship between the ISGT index and the number of Airbnb accommodations.

Some research, in addition to linking Airbnb with urban gentrification and urban metabolism, has also linked it with processes of social exclusion, and with the decrease and deterioration of the quality of life of the resident population [76-78]. In light of the above, we propose Hypothesis 3. 
Hypothesis 3 (H3). There is a negative relationship between social and economic cohesion and the number of Airbnb accommodations in each neighborhood.

In addition to the perceived change in the tangible characteristics of the neighborhoods, another concern about the rapid expansion of Airbnb is regarding the safety problems that a greater concentration of people in the places can cause. Tourism and hospitality are very susceptible to criminal activities. Visitors who stay in rentals on this platform may be more exposed to a greater variety of crimes because they are not in tourist places [79].

According to Xu's research [79] in the state of Florida, he found that Airbnb is positively related to the location of apartments and criminal activity, especially against property crimes. However, although Airbnb is related to crime, in Xu's case study, the relationship to the violent crime was significant but negative. In addition, the relationship between crimes varies according to the type of accommodation (private rooms, shared rooms, and whole houses). While private rooms and whole houses have negative correlations with crime, shared rooms are positively related to crime. In line with that set out above, the following hypothesis is put forward:

Hypothesis 4 (H4). There is a negative relationship between residents' perception of the quality of public space and the number of Airbnb accommodations in each neighborhood.

Hypothesis 4a (H4a). Negative relationship between security and the number of Airbnb accommodations in each neighborhood.

Airbnb tends to focus on areas with pre-established tertiary activity and, which in turn is attractive to tourists [80]. In the case of Madrid, the neighborhood with the highest concentration of tourist rentals coincides with strong commercial activity. The high correlation between tertiary activity and Airbnb can change the urban structure of neighborhoods [81]. The above allows us to formulate Hypothesis 5.

Hypothesis $\mathbf{5}$ (H5). There is a negative relationship between the urban complexity indicator and the number of Airbnb accommodations.

Hypothesis 5a (H5a). Positive relationship between tertiary activity imbalance and Airbnb rise.

Other studies have also looked at the socio-economic and environmental dimensions of Airbnb rentals from different perspectives and in several cities. Until now, the Geographically Weighted Regression (GWR) model has been the most popular technique for modeling the spatial heterogeneity of different Airbnb-related factors. Xu [79] modeled the spatial distribution of Airbnb rentals in the state of Florida and found a positive correlation between Airbnb groupings and crime rates. Zhang [67] also used GWR and found significant variations between Airbnb prices and the distance to the main tourist and transport points (subway and bus stations). Xu [82] uses GWR to test Airbnb's non-stationary spatial distribution and its relationship with the neighborhood environment in London, and, finally, Lagonigro [37] studied the local socio-demographic and economic factors of the city of Barcelona associated with geographic distribution from Airbnb.

In our research, we adopted a Spatial Autoregressive Panel Data Model (SAR) as an estimation model, we focusing on local economic, environmental, and social factors related to the spatial distribution of Airbnb's supply, for the time period 2015-2018 in the Madrid. The use of spatial panel models has been used to model the existence of spatial dependence between the dependent variable and between the independent variables in time, working with the transversal units over time.

This methodological choice is due to the fact that the SAR model allows modeling the spatial heterogeneity of the variables in panel data, improving the results of the GWR model, which is a local form of linear regression that is used to model the relationships that vary spatially in sets of cross-section data. In the literature, we can find the use of SAR for 
the estimation of hedonic prices for the flats listed on Airbnb [83] and in some other studies besides structural variables are used environmental, social, and spatial variables of the neighborhoods where this platform is located $[84,85]$. The SAR model is a representation of a random process, where the variable of interest depends on your past observations.

In terms of our research, the variable of interest is the proportion of complete Airbnb houses in the total supply. In each year, the number of complete houses depends on the environmental, social, and economic conditions of the neighborhoods. However, environmental and social conditions may not change (or do so very slowly) to dramatically influence the increase in whole houses. Economic factors, on the other hand, can change dramatically from year to year. We could argue that in most years (on average) the economic conditions of the neighborhoods are optimal. However, there are years in which, for example, the economic indicators of the neighborhoods suffer very marked ups and downs. We say that these ups and downs are a disturbance: it moves our variable (the total of complete houses) away from its long-term equilibrium (equilibrium in which economic conditions are good on average). As social and environmental qualities change slowly from year to year, the total number of houses completed in any given year will be partially influenced by the number in the previous year. The variation in the changes in the total of complete houses will be given by the disturbances, the economic factors.

Finally, given that spatial models allow us to infer whether economic and social phenomena have a spillover effect, we establish Hypothesis 6.

Hypothesis 6 (H6). There is a spillover effect due to the positive relationship between touristification in the neighborhood " $i$ " and the number of Airbnb accommodations in neighboring neighborhoods " $j$ ".

Hypothesis 6a (H6a). Negative relationship between the resident population 0 to 15 years of age in the neighborhood " $i$ " and the number of Airbnb accommodations in neighborhood " $j$ ".

Hypothesis $\mathbf{6 b} \mathbf{( H 6 b ) . ~ N e g a t i v e ~ r e l a t i o n s h i p ~ b e t w e e n ~ t h e ~ r e s i d e n t ~ p o p u l a t i o n ~ o v e r ~} 65$ years of the neighborhood " $i$ " and the number of Airbnb accommodations in the bordering neighborhood " $j$ ".

Hypothesis 6c (H6c). Positive relationship between the increase in noise and urban waste in neighborhood " $i$ " and the number of Airbnb accommodations in neighborhood bordering " $j$ ".

Hypothesis 6d (H6d). Positive relationship between the increase in the ISGT index in the neighborhood " $i$ " and the number of Airbnb accommodations in neighborhood borderline " $j$ ".

Given all of the above, this study seeks to analyze the evolution of Airbnb in Madrid neighborhoods through urban sustainability indicators that reflect the effects of overtourism, touristification and gentrification processes.

In Appendix A, the reader can see graphically the relationship of the hypotheses with the explanatory variables of the model and the number of Airbnb accommodations, according to the three pillars of urban sustainability.

\section{Methodology}

\subsection{Area Studied}

Spain is the nation in which Airbnb generates the third-highest activity in the world, behind only the United States and France. The global figure for the platform's largest 25 markets shows that the economic footprint of this business model was over EUR 83,380 million in 2018. The US ranks first, with an expenditure of EUR 28,629 million, followed by France with 9148 million, and Spain with 5844 million.

Madrid's prominence led us to choose it as the city in which to analyze the impact of Airbnb on urban sustainability. In 2018, the number of tourists Madrid received reached 10.2 million, growth that some authors classify as a "tourist bubble" [86]. This phenomenon 
positions tourist activity as one of the main economic activities of the Spanish capital and has consolidated Spain as the second-largest tourism power worldwide.

This large influx of visitors has a tremendous economic and social impact on the city, generating over 25 million euros a day and over 390,000 jobs in tourism [87]. However, it also produces great stress in the city center.

According to the population register as of 1 January 2018, Madrid had a total of $3,221,824$ inhabitants, of which approximately $4 \%$ live in the Downtown district of the city. This district could be taken as an example of the relationship between gentrification and the increase in Airbnb tourist apartments in the city.

The Centro district is the most densely populated in the city, with 253 inhabitants per hectare, with a strong progressive reduction in the child population. The low number of children living in the district is due, on the one hand, to the fact that it has the lowest birth rate in the entire city (7.32 compared to the city average of 9.00$)$ and a negative rate of natural growth ( -0.61 versus 0.55 on average in the city). However, in the six neighborhoods that make up the Centro district, the number of inhabitants between the ages of 25 and 39 is one of the highest in Madrid (41,021 people), which clearly indicates that families move to other parts of the city. The city and are replaced by young people, as shown by the fact that the number of births is higher in the periphery than in the center (Madrid City Council, 2019a).

On the other hand, urban transformation projects that promote the pedestrianization of central neighborhoods have a double opposite effect. On the one hand, they represent notable improvements in the quality of public space and sustainable mobility, but on the other, they have generated undesirable effects, such as the expulsion and displacement of traditional small businesses, replaced by franchises and multinationals. This urban model inevitably consolidates processes of exclusion, gentrification, and socio-spatial segregation that drive the loss of diversity, identity, and complexity in urban centers $[55,58,59,88,89]$.

\subsection{Data}

For this study, the data obtained on Airbnb was taken mainly from the Inside Airbnb website (http:/ / insideairbnb.com/ (accessed on 12 March 2021)). This data contains public information that is collected from the Airbnb website, which includes the location of all its accommodations, as well as the availability of the homes throughout the 365 days of the year. This data is available for over 30 cities in Europe, the United States, Canada, and Australia. The Airbnb data collected for the city of Madrid covers the period of 2015-2018 and consists of the number of accommodation by type (complete apartments, private rooms, shared rooms); number of beds; the geographic location according to $\mathrm{X}$, $\mathrm{Y}$ coordinates.

On the map (Figure 1) you can see the distribution of the platform's accommodations across the city, it being well known that Airbnb is concentrated in the central neighborhoods. In Appendix A, the reader can find information for each of the neighborhoods. For the set of data used to measure sustainability, 13 urban sustainability indicators were used, which are key to the definition and organization of the city in an urban sustainability model [89].

The selection of these indicators are based on the principles of the Leipzig Charter [7] and the Toledo Declaration [90], on the Indicators of the UN-Habitat Agenda [6], and the system of indicators and conditions for large cities and medians from the Barcelona Urban Ecology Agency [89]. 


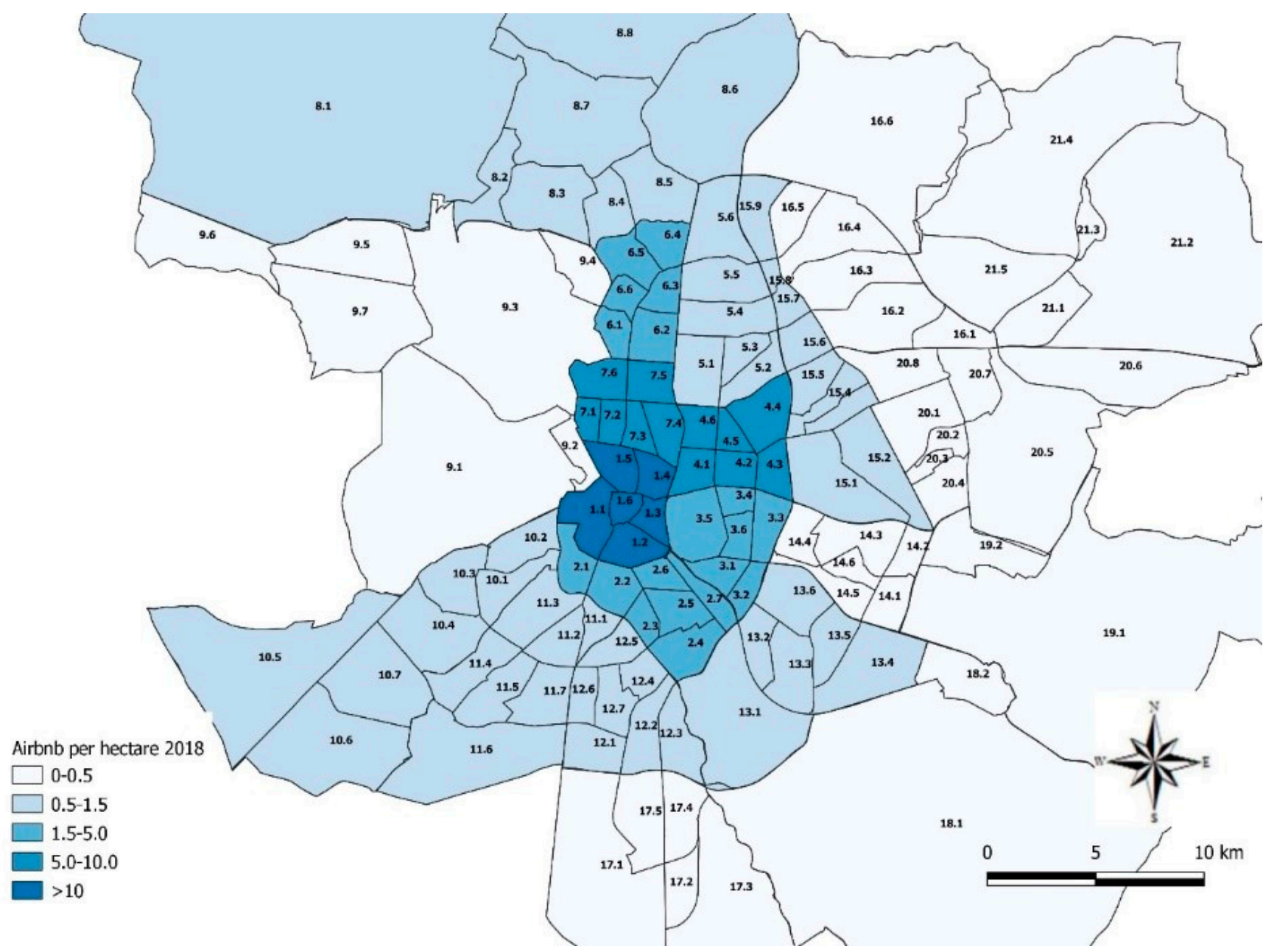

Figure 1. Distribution by hectares of Total Airbnb accommodations in the neighborhoods of the districts of the city of Madrid 2018 (unit accommodation numbers).

The use of indicators facilitates the understanding of the evolution of urban systems over time. The construction of these indicators was carried out with data from 128 neighborhoods, offered by the Madrid city council through its open data web portal (www.datos.madrid.es/portal/site/egob/ (accessed on 10 March 2021)), the survey "Calidad de Vida y Satisfacción con los Servicios Públicos de la Ciudad de Madrid" (https: / / cutt.ly/7jblf9b (accessed on 10 March 2021)) and its statistics portal (https://n9.cl/wtvf (accessed on 10 March 2021)). As there is no single system of indicators that can be applied in a generic and universal way because the indicators respond to the interpretation that is made of the reality to be analyzed [91], we selected indicators are based on the three pillars of sustainability (economic, environmental and social), and they allow us the measurement of four subsystems:

- "Quality of public space" (comfort and acoustic safety): Public space is the structural component of a more sustainable city model. It is the space for citizen coexistence and forms one of the main axes of social life and relationships.

- "Urban complexity" (balance of tertiary activity): Urban complexity reflects the interactions established in a city between economic activities, institutions, and associations. Through urban complexity, an attempt is made to bring people closer to services and jobs. In addition, the complexity indicators show the maturity of the urban fabric and the wealth of economic and social capital.

- The "urban metabolism" (generation of waste) is related to the efficiency of the management of the natural resources of the city. We propose to analyze the cycles of 
urban metabolism beginning with the generation of waste. If the seasonal increase in the consumption of resources and the production of waste increases to unsustainable amounts, significant costs (economic, social, and environmental) are generated, which put at risk the attributes of the place and the environmental quality of the destination in general.

- "Social and economic cohesion" deals with people and social and economic relationships within the urban system. The social mix of cultures, ages, and income levels has stabilizing effects on the urban structure, since it presupposes a balance within the city. Analyzing this diversity shows those who occupy the space the ways in which they can interrelate with the components that make up the neighborhood or city.

Table 2 collects the variables used in the research grouped according to the sustainability pillars, subsystems, and types of variables.

Table 2. Description of database variables.

\begin{tabular}{|c|c|c|c|c|c|}
\hline Type of Variable & Subsystem & Variables & Description & Units & Source \\
\hline $\begin{array}{l}\text { Dependent } \\
\text { variable }\end{array}$ & & Airbnb & $\begin{array}{c}\text { The quotient of entire houses } \\
\text { offered via Airbnb between } \\
\text { the total offer of } \\
\text { accommodation on the } \\
\text { platform }\end{array}$ & $\begin{array}{c}\text { \% complete houses' } \\
\text { Airbnb }\end{array}$ & Inside Airbnb \\
\hline \multicolumn{6}{|c|}{ Exogenous variables (pillar of sustainability) } \\
\hline \multirow{5}{*}{ Social } & $\begin{array}{l}\text { Social and economic } \\
\text { cohesion }\end{array}$ & Phed & $\begin{array}{l}\text { Proportion of population } \\
\text { with higher education }\end{array}$ & $\begin{array}{l}\text { \% Population with } \\
\text { higher education }\end{array}$ & Madrid City Council \\
\hline & $\begin{array}{l}\text { Social and economic } \\
\text { cohesion }\end{array}$ & Childr & $\begin{array}{l}\text { Total population } 0-15 \text { years } \\
\text { old in the neighborhood }\end{array}$ & Number of people & Madrid City Council \\
\hline & $\begin{array}{l}\text { Social and economic } \\
\text { cohesion }\end{array}$ & Older & $\begin{array}{l}\text { Total population over } 65 \text { in } \\
\text { the neighborhood }\end{array}$ & Number of people & Madrid City Council \\
\hline & $\begin{array}{l}\text { Social and economic } \\
\text { cohesion }\end{array}$ & Employ & $\begin{array}{c}\text { Total number of employed } \\
\text { population in the } \\
\text { neighborhood }\end{array}$ & Number of people & Madrid City Council \\
\hline & Public space & Safety_day & $\begin{array}{c}\text { Inhabitants' perception of } \\
\text { safety of neighborhood } \\
\text { during the day.* }\end{array}$ & $\begin{array}{l}\text { Synthetic indicator } \\
\qquad 0-100 .\end{array}$ & $\begin{array}{l}\text { Panel of indicators of } \\
\text { districts and } \\
\text { neighborhoods from } \\
\text { Madrid City Council }\end{array}$ \\
\hline \multirow{3}{*}{ Environmental } & Public space & Noise & $\begin{array}{l}\text { Disturbances from noise in } \\
\text { neighborhood due to } \\
\text { commercial establishments, } \\
\text { roads, etc. }{ }^{*}\end{array}$ & $\begin{array}{l}\text { Synthetic indicator } \\
\qquad 0-100 .\end{array}$ & $\begin{array}{l}\text { Open data from } \\
\text { Madrid City Council }\end{array}$ \\
\hline & Urban metabolism & Waste & $\begin{array}{c}\text { Daily production of solid } \\
\text { waste generated by residents } \\
\text { and tourists }\end{array}$ & $\begin{array}{l}\mathrm{Kg} \text { of waste per } \\
\text { person }\end{array}$ & Madrid City Council \\
\hline & Urban complexity & Eqact & $\begin{array}{l}\text { Ratio of gross floor area of } \\
\text { tertiary activity vs. total gross } \\
\text { floor area. }\end{array}$ & $m^{2}$ & Madrid City Council \\
\hline \multirow{4}{*}{ Economic } & $\begin{array}{l}\text { Social and economic } \\
\text { cohesion }\end{array}$ & $\begin{array}{l}\text { Global Indicator } \\
\text { of Tourism Stress. } \\
\text { (ISGT) }\end{array}$ & $\begin{array}{l}\text { The sum of hotel beds and the } \\
\text { sum of Airbnb beds for a } \\
\text { surface reference (in this case } \\
\text { each neighborhood) }\end{array}$ & $\%$ & $\begin{array}{c}\text { Authors' calculation, } \\
\text { using methodology } \\
\text { of Ayllon (2018) }\end{array}$ \\
\hline & $\begin{array}{l}\text { Social and economic } \\
\text { cohesion }\end{array}$ & Income & Mean household income & Euros $(€)$ & Madrid City Council \\
\hline & $\begin{array}{l}\text { Social and economic } \\
\text { cohesion }\end{array}$ & Rentl & $\begin{array}{l}\text { Long-term residential rental } \\
\text { price }\end{array}$ & $\begin{array}{l}\text { Thousands of euros } \\
\text { per square meter }\end{array}$ & Madrid City Council \\
\hline & $\begin{array}{l}\text { Social and economic } \\
\text { cohesion }\end{array}$ & Price & House price & $\begin{array}{l}\text { Thousands of euros } \\
\text { per square meter }\end{array}$ & Madrid City Council \\
\hline
\end{tabular}


In Table 3, the descriptive statistics of the variables to be used in the research are developed.

Table 3. Descriptive statistics of database variables.

\begin{tabular}{cccccc}
\hline Variable & Obs & Mean & Std. Dev. & Min & Max \\
\hline Airbnb & 512 & 0.3938384 & 0.1926467 & 0 & 0.82756 \\
Psup & 512 & 458.593 & 594.6386 & 55.21949 & 4393.833 \\
Childr & 512 & 3350.895 & 2395.897 & 230 & 16782 \\
Older & 512 & 5071.381 & 3256.562 & 104 & 19890 \\
Employ & 512 & 9092.064 & 5436.732 & 408 & 35534 \\
Safety_day & 512 & 74.80004 & 6.523683 & 56.7 & 86.2 \\
Noise & 512 & 3.315671 & 2.088801 & 0.05 & 8.575 \\
Waste & 512 & 57.56897 & 66.97399 & 0.8995482 & 535.7117 \\
Eqact & 512 & 0.3499344 & 0.1313478 & 0 & 0.8153415 \\
Global indicator of tourism stress (ISGT) & 512 & 8.780596 & 24.65839 & 0 & 280.6396 \\
Income & 512 & 41338.6 & 16829.71 & 535.0852 & 143227.9 \\
Price & 512 & 2768.224 & 1166.77 & 664.9286 & 7931 \\
Rentl & 512 & 12.23919 & 2.745184 & 7.617647 & 20.95278 \\
\hline
\end{tabular}

Table 3 shows us interesting results regarding the variables. In Madrid, the average Airbnb offer of complete houses is 39\%; however, there are neighborhoods in which the total offer of accommodation on this platform reaches almost $83 \%$. Taking into account that in 2018 the total Airbnb offer reached a total of 18,267 listings, these figures mentioned above may represent a significant decrease in the stock of long-term housing (Homeownership and residential rental). According to the Global Indicator of Tourist Stress, we can say that in Madrid neighborhoods, although these are not touristy, they will always have an average of approximately 9 beds tourist accommodation places and a maximum of 280 beds tourist available.

With reference to the variables that are mostly associated with the presence of Airbnb in the Spanish capital, the perception of noise on average does not seem to be an important factor, on a scale of 0 to 10 , the neighbors report a perception of 3.3. However, the maximum for this variable is 8.5 , which means that neighborhoods with a higher saturation of tourist apartments are affected by this tourism externality. Safety, which is a key issue in places with overtourism, for the particular case of Madrid, the perception is quite good, with an average of 56.7 and with a maximum of 86.2 , on a scale from 0 to 100 . The variables described above enable us to analyze the evolution of Airbnb in Madrid neighborhoods, specifically on the pillars of urban sustainability from the 2030 agenda.

\section{Specification of the Econometric Model}

Although the literature on spatial econometrics is divided on how to tackle and choose the best spatial model, this study uses the method proposed by $[10,11]$ to analyze the impact of the spatial distribution of Airbnb on sustainability indicators in Madrid.

The simplest model for analyzing a panel of data is to estimate a regression by Ordinary Least Squares. This model does not include either the spatial or the temporal dimensions of the data and assumes that the constant in the model is the same for all cross-sectional and time units. The linear model without spatial effects can be expressed as:

$$
Y=\iota_{N} \alpha+X \beta+\varepsilon
$$

where

$Y$ is a vector of dimension NT $\times 1$ that corresponds to the observations of the dependent variable for each cross-section or spatial units $i$, where $i=1,2 \ldots N$, and time dimension $t$, where $t=1,2, \ldots \mathrm{T}$,

$X$ is the matrix that contains the k exogenous explanatory variables for each cross-section $\mathrm{i}$ in the time dimension $t$.

$\beta$ is the K-dimensional vector of associated coefficients $\beta$, $\alpha$ is the intercept of the equation, 
$\varepsilon$ is a vector of error terms independently and identically distributed over dimension NTx1, which includes the unobservable heterogeneity produced by variables that change both across the cross-sections or spatial units and over time.

Two models exist to estimate the individual nature of each spatial and/or time unit: the fixed effects model and the random effects model. The fixed effects model estimates that the effect has a fixed value for each cross-sectional and/or time unit-that is, that differences among cross-sectional and/or time units are constant.

$$
Y_{t}=\iota_{N} \alpha_{t}+X_{t} \beta+\mu_{t}+\vartheta_{t}+\varepsilon_{t}
$$

where:

$\mathrm{\imath N} \alpha$ is the intercept of the equation represented by $\alpha$ and $\mathrm{\imath N}$, which is the unit vector of dimension $\mathrm{N}$.

$\mu_{t}$ is the spatial effect that includes the unobservable heterogeneity produced by variables that change across each cross-section or spatial units $i$, but remain constant over time. It is a vector of dimension $\mathrm{N} \times 1$.

$\vartheta_{t}$ is the time effect that includes the unobservable heterogeneity produced by variables that change over time but remain constant across each cross-section or spatial units i. It is a vector of dimension $\mathrm{T}$.

$\varepsilon_{t}$ is a vector of independently and identically distributed error terms of dimension NTx1, which includes the unobservable heterogeneity produced by variables that change both across the cross-sections or spatial units and over time.

For the case of our investigation, Equation (2) in its vector form and with the variables of our investigation is the following:

$$
\begin{aligned}
& \text { Airbnb }_{i t}=\iota_{N} \alpha_{t}+\beta_{1} \text { Safety }_{\text {day }_{\text {it }}}+\beta_{2} \text { phed }_{\text {it }}+\beta_{3} \log _{\text {childr }}+\beta_{\text {it }} \text { older }_{\text {it }} \\
& +\beta_{5} \text { lemploy }_{\text {it }}+\beta_{6} \text { Noise }_{i t}+\beta_{7} \text { Log }_{-} \text {waste }_{i t}+\beta_{8} \text { Eqact }_{\text {it }} \\
& +\beta_{9} \text { ISGT }_{\text {it }}+\beta_{10} \log \_ \text {income }_{i t}+\beta_{11} \text { drentl }_{\text {it }}+\beta_{12} \text { pricelag }_{\text {it }} \\
& +\mu_{t}+\vartheta_{t}+\varepsilon_{t}
\end{aligned}
$$

where:

- $A i r b n b_{i t}=$ percentage of complete homes offered on Airbnb among the total number of accommodations on the platform in the neighborhood " $i$ " in the period " $t$ ".

- Safety $_{\text {day }_{\text {it }}}=$ collects the responses of the residents of the neighborhood " $\mathrm{i}$ " in the time period " $\mathrm{t}$ " to the question "Could you tell me how safe you feel during the day in the neighborhood or area where you live?" from the annual survey "Quality of Life and Satisfaction with the Public Services of the City of Madrid", which scores from 1-4, 1 being: not at all safe, 2: Not very safe, 3: Quite a bit, 4: Very. This variable has been transformed into a direct synthetic index from 0 to 100 since 4 is better than 1 .

- $\quad \operatorname{phed}_{\mathrm{it}}=$ Percentage of population with higher education among the total population in the neighborhood " $\mathrm{i}$ " in the time period " $\mathrm{t}$ ".

- $\operatorname{logchildr}_{i t}=$ natural logarithm of the population aged 0 to 15 in the neighborhood " $\mathrm{i}$ " in the time period " $\mathrm{t}$ ".

- older $_{i t}=$ population over 65 years of age in the neighborhood " $\mathrm{i}$ " in period " $\mathrm{t}$ "

- $\quad$ lemploy $_{i t}=$ natural logarithm of the employed population of the neighborhood " $\mathrm{i}$ " in period " $\mathrm{t}$ ".

- Noise $_{i t}=$ collects the responses of the residents of the neighborhood " $\mathrm{i}$ " in the time period " $t$ " to the question: "Noise nuisance (premises, public roads ... )", from the survey "Quality of Life and Satisfaction with Public Services of the City of Madrid", which scores from 0 to 10 , where 0 : little noisy and 10: very noisy. This variable has been transformed into an inverse synthetic indicator from 0 to 100 , so that in this way the indicator closer to 100 is a better indicator.

- $\quad$ Log_waste $_{i t}=$ natural logarithm of the proportion of daily solid waste production (in $\mathrm{kg}$ per individual) of inhabitants and tourists of the neighborhood " $\mathrm{i}$ " in period " $\mathrm{t}$ ". 
- $\quad$ Eqact $_{\text {it }}=$ proportion of the constructed area for tertiary activities among the total constructed area of the neighborhood " $\mathrm{i}$ " in period " $\mathrm{t}$ ".

- $\quad \mathrm{ISGT}_{\mathrm{it}}=$ Global Index of Tourist Saturation of neighborhood $\mathrm{i}$ in the time period " $\mathrm{t}$ ".

- $\quad \log$ income $_{i t}=$ natural logarithm of the average household income expressed in euros in the neighborhood " $\mathrm{i}$ " in the time period " $\mathrm{t}$ ".

- $\mathrm{drent}_{\mathrm{it}}=$ variation of the rental price in the neighborhood " $\mathrm{i}$ " in time period $\mathrm{t}$ and $\mathrm{t}-1$ and 1.

- pricelag $_{\mathrm{it}}=$ Price of the purchase and sale of houses in year $\mathrm{t}-1$ of the neighborhood " $\mathrm{i}$ ".

The random effects model, in contrast, considers the effect as a random variable with an average and a non-zero variance; that is, it views differences among cross-sectional and/or time units as random [92].

$$
Y_{t}=i_{N} \alpha_{t}+X_{t} \beta+\varnothing+\varepsilon_{t}
$$

where:

$\varnothing$ is the random independently and identically distributed spatial effect with average 0 and variance $\sigma 2 \neq 0$; ref. [11] advises using a fixed effects model from the beginning instead of a random effects model, because databases of spatial models tend to work with space-time data of adjacent spatial units located in uninterrupted study areas.

The Lagrange Multiplier (LM) test enables us to determine whether is it significant to include in the panel data model the spatial lag of spatial dependence on the dependent variable or on the error term. To do so, the test studies the interrelation of the spatial effects on the cross-sectional data and is based on the values of the log-likelihood function of different models. The null hypothesis states that the dependent variable or the error term are not spatially self-correlated and should be rejected with a significance level of $5 \%$ or $1 \%$, implying inclusion of the lagged or spatial dependence term on the dependent variable or the error. This test was proposed by $[93,94]$.

Once the model is determined to have substantive spatial dependence (on the dependent variable) or residual dependence (on the regression error term), one must select the best spatial model. Following the strategy described in [11,95], the best strategy is to begin with the Spatial Durbin Model (SDM) as a general specification (General Nesting Spatial Model), expressed as follows:

$$
\begin{gathered}
Y_{t}=\rho W y_{t}+i_{N} \alpha_{t}+X_{t} \beta+W X_{t} \theta+\varepsilon_{t} \\
\varepsilon_{t}=\lambda W \varepsilon_{t}+u_{t}
\end{gathered}
$$

where:

$y$ is a vector of dimension $N T \times 1$ that corresponds to the observations of the dependent variable for each neighborhood $i$ and year $t$.

$W$ (normalized row) is a matrix of spatial weightings or neighborhoods of dimension $N \times N$, whose interaction (i,j)-th element has some finite and positive value if neighborhoods $i$ and $j$ interact, and zero if not.

$\rho$ is the spatial autoregressive parameter associated with the dependent variable, which represents the intensity of spatial self-correlation.

Wy captures the presence of the secondary effects.

$X$ is a matrix of dimension $N T \times k$ of observations of explanatory variables, where $\mathrm{k}$ is the number of exogenous variables.

$\beta$ is a vector of unknown parameters associated with independent variables of dimension $k \times 1$.

$\boldsymbol{\theta}$ is a vector of dimension $k \times 1$ of spatial parameters associated with independent variables (WXit).

$u$ is the spatial fixed effect that includes the unobservable heterogeneity produced by variables that change across neighborhoods but remain constant over time. It is a vector of dimension $N \times 1$. 
$\lambda$ is the Wut spatial coefficient.

$\varepsilon$ is a vector of independently and identically distributed error terms of dimension $N T \times 1$, which includes the unobservable heterogeneity produced by variables that change both across neighborhoods and over time.

For this study, we considered a row-standardized matrix of four nearest neighbors. This decision follows the traditional way of using the geographical criterion in the first law of geography: "Everything is related to everything else, but near things are more related than distant things" [96]. With this criterion, we use the information from the centroids and continue to choose the nearest neighbor to the centroid until we obtain the number of 4 neighbors. Based on this reasoning, all regions will have the same number of neighbors, thus avoiding the problem of isolated units or units with a very large number of neighbors. Once we have defined the criterion of neighborhood, the set of neighbors is represented by the distance among spatial units.

Starting from the expression in Equation (4), the panel data SDM [11] with which we work is expressed as follows, taking the value $\lambda=0$ :

$$
Y_{t}=\rho W y_{t}+i_{N} \alpha_{t}+\beta X_{t}+W X_{t} \theta+u_{t}
$$

After estimating the SDM, we must test whether the SDM can be simplified to a spatial lag model $H_{0}: \rho=0$, or a spatial error model $H_{0}: \rho+\theta \beta=0[11,97]$. Both tests follow a Chi-square distribution with $\mathrm{K}$ degrees of freedom.

Correct interpretation of space-time models with spatial dependence on the dependent variable or on the explanatory variables should not be understood as simple partial derivatives. These models can generate a spillover process [11,98]. The total spillover indicates changes in one dependent variable in a specific spatial unit that directly affect the dependent variable of that spatial unit but will also indirectly affect these neighbors' neighbors, causing a feedback effect. Spillover is thus represented as the sum of the direct and indirect effects [99]. Table 4 shows the direct and indirect effects for the different spatial panel models.

Table 4. Direct and indirect effects for different spatial panel models.

\begin{tabular}{ccc}
\hline Model & Direct Effect & Indirect Effect \\
\hline Basic & $\beta$ & 0 \\
SEM & $\beta$ & 0 \\
SAR & Diagonal element & Elements outside the diagonal \\
& $\left(I_{i t}-\rho W\right)^{-1} \times\left(\beta I_{i t}\right)$ & $\left(I_{i t}-\rho W\right)^{-1} \times\left(\beta I_{i t}\right)$ \\
SDM & Diagonal element & Elements outside the diagonal \\
& $\left(I_{i t}-\rho W\right)^{-1} \times\left(\beta I_{i t}+\theta_{k} W\right)$ & $\left(I_{i t}-\rho W\right)^{-1} \times\left(\beta I_{i t}+\theta_{k} W\right)$ \\
\hline
\end{tabular}

For all models, the $\mathrm{W}$ matrix is decomposed as follows:

$$
\left(I_{i t}-\theta W\right)^{-1}=I_{i t}+\theta W+\theta^{2} W^{2}+\theta^{3} W^{3} \ldots
$$

where $I_{i t}$ is the identity matrix of dimension $N T \times 1$, and $W$ is the spatial weights matrix. When $W$ is raised to the power of 1 , it represents the first-order neighbors. The matrix with superscript 2 indicates the second-order neighbors, that is, neighbors of the firstorder neighbors, and so on [95]. Equation (8) represents the effects that occur through the neighboring units and return to the original spatial unit.

\section{Results}

Table 5, in the second column, summarizes the results (equation 1) of the pooled or basic model estimated without spatial effects to examine the evolution of Airbnb rentals as the dependent variable and of the tests to determine which model is better: the spatial lag model or the spatial error model. According to [11], classic LM tests should be used, both 
for the hypothesis on the spatially lagged dependent variable and for the hypothesis on the spatially self-correlated error term. The tests should be rejected at $5 \%$ and $1 \%$ significance, independently of whether they include fixed effects for space and/or time.

Table 5. Results of evolution of Airbnb on urban sustainability indicators.

\begin{tabular}{|c|c|c|c|c|c|c|c|}
\hline Variables & Basic & $\begin{array}{l}\text { SDM with Fixed } \\
\text { Spatial Effects }\end{array}$ & $\begin{array}{l}\text { SDM with Fixed } \\
\text { Temporal Effects }\end{array}$ & $\begin{array}{l}\text { SDM with Fixed } \\
\text { Spatial and } \\
\text { Temporal Effects }\end{array}$ & $\begin{array}{l}\text { SAR with Fixed } \\
\text { Temporal Effects }\end{array}$ & $\begin{array}{l}\text { SEM with Fixed } \\
\text { Temporal Effects }\end{array}$ & $\begin{array}{l}\text { SARAR with } \\
\text { Fixed Temporal } \\
\text { Effects }\end{array}$ \\
\hline Safety_day & $0.004^{* * *}$ & -0.0007 & -0.0033 & -0.0007 & $0.0027^{* *}$ & 0.0015 & $-0.0037^{*}$ \\
\hline hed & 0 & $0.00003^{* * *}$ & 0.00002 & $2.40 \times 10^{-5 * *}$ & 0 & 0 & 0 \\
\hline logchildr & $-0.171^{* * *}$ & $0.0822^{* * *}$ & -0.09999 & $0.0898^{*}$ & $-0.1355^{* * *}$ & $-0.1125^{* * *}$ & $-0.1115^{* * *}$ \\
\hline older & $-\underset{* * *}{0.167 \times 10^{-5}}$ & $2.08 \times 10^{-5}$ & $-0.00002^{* * *}$ & $2.32 \times 10^{-5 *}$ & $1.61 \times 10^{-4 * * *}$ & $-1.37 \times 10^{-5 * * *}$ & $-1.49 \times 10^{-6 * * *}$ \\
\hline lemploy & $0.265^{* * *}$ & 0.0133 & $0.18024^{* * *}$ & 0.0106 & $0.2009^{* * *}$ & $0.2387^{* * *}$ & $0.1693^{* * *}$ \\
\hline Noise & $0.015^{* * *}$ & 0.001255 & $0.00743^{* *}$ & $1.25 \times 10^{-3}$ & $0.008^{*}$ & $0.0076^{*}$ & 0.0023 \\
\hline Log_waste & $0.031^{* * *}$ & $0.0497^{*}$ & $0.02803^{* * *}$ & 0.037 & $0.0308^{* * *}$ & $0.0302^{* * *}$ & $0.0305^{* * *}$ \\
\hline Eqact & $0.244^{* * *}$ & $-0.0528^{*}$ & $0.20446^{* * *}$ & $-0.0557 * *$ & $0.2209 * * *$ & $0.1921^{* * *}$ & $0.1973 * * *$ \\
\hline ISGT & 0.001 & -0.0006 & $-0.00009 *$ & -0.0006 & 0.0002 & 0 & -0.0003 \\
\hline log_income & $0.084^{* * *}$ & 0.0087 & 0.02143 & -0.0006 & $0.0553 * * *$ & $0.0492 * * *$ & 0.0211 \\
\hline drentl & $0.046^{* * *}$ & 0.0016 & 0.0370 * & 0.0127 & $0.0403^{* * *}$ & $0.0248 * *$ & $0.0367^{* *}$ \\
\hline pricelag & $0.03^{* * *}$ & $0.011 *$ & 0.01711 & $-0.0008^{*}$ & $0.024^{* * *}$ & $0.0214^{* *}$ & 0.0162 \\
\hline$\rho$ & & $-0.0234^{* * *}$ & $0.14736^{* * *}$ & $-0.05109^{* * *}$ & $0.2908^{* * *}$ & $0.4797^{* * *}$ & $0.1205^{* * *}$ \\
\hline$\lambda$ & & & & & & $-0.3559 * * *$ & \\
\hline$\sigma^{2}$ & & $0.0025^{* * *}$ & $0.015053 * * *$ & $0.002417^{* * *}$ & $0.0161^{* * *}$ & $0.0145^{* * *}$ & $0.01475^{* * *}$ \\
\hline Observations & 512 & 512 & 512 & 512 & 512 & 512 & 512 \\
\hline R-squared & 0.5121 & & & & & & \\
\hline Spatial error & & & & & & & \\
\hline Moran's I & $3.975 * * *$ & & & & & & \\
\hline $\begin{array}{l}\text { Lagrange } \\
\text { multiplier }\end{array}$ & $13.993 * * *$ & & & & & & \\
\hline $\begin{array}{c}\text { Robust Lagrange } \\
\text { multiplier }\end{array}$ & $9.84^{* * *}$ & & & & & & \\
\hline Spatial lag: & & & & & & & \\
\hline $\begin{array}{l}\text { Lagrange } \\
\text { multiplier }\end{array}$ & $46.344^{* * *}$ & & & & & & \\
\hline $\begin{array}{l}\text { Robust Lagrange } \\
\text { multiplier }\end{array}$ & $42.19^{* * *}$ & & & & & & \\
\hline Log-Lik & & 811.8526 & 346.2054 & 815.7226 & 324.432 & 332.0476 & 351.8226 \\
\hline$R_{w}$ & & 0.1612 & 0.0102 & 0.1399 & 0.007 & 0.0114 & 0.0109 \\
\hline$R_{b}$ & & 0.174 & 0.665 & 0.224 & 0.6296 & 0.6356 & 0.67 \\
\hline$R$ & & 0.0145 & 0.5833 & 0.0191 & 0.5397 & 0.5527 & 0.5837 \\
\hline Hausman $\chi^{2}$ & & 83.32 & 64.13 & 87.62 & 44.24 & & 67.78 \\
\hline \multicolumn{2}{|c|}{ Hausman $p$-value } & 0 & 0 & 0 & 0 & & 0 \\
\hline
\end{tabular}

Similarly, when robust tests are used, the hypotheses that do not have a spatially self-correlated error term must be rejected at $5 \%$ and $1 \%$ significance. As can be seen in Table 4, the LM and robust LM tests are rejected at this significance level and suggest that the model has both residual and substantive spatial dependence.

Based on these results, we will next estimate our equation according to the specifications of a Durbin model, as [95] propose, with spatial and temporal fixed effects, as [11] recommends. Elhorst's [11] recommendation is supported by evidence from the last two lines of Table 4, where all specifications of static random effects are strongly rejected by the Hausman test, indicating that we should work with a fixed effects model.

Table 5 on the sixth to eighth columns shows strong spatial interactions of the effects of Airbnb on sustainability indicators in the city of Madrid. The spatially lagged coefficient 
of the dependent variable $(\rho)$ is highly significant. For the impact of Airbnb, the large differences between $R_{w}^{2}$ and $R_{b}^{2}$ confirm the importance of the fixed effects associated with variables that are not included in the analysis and that cannot be identified in this specification. A $R^{2}$ of at least 0.58 shows, however, that the models can represent a large proportion of the temporal variance of Airbnb's impact on the city of Madrid.

The results on Table 6 strengthen the recommendations by [11,95] to begin with an SDM model as general specification.

Table 6. Test for model selection.

\begin{tabular}{cccc}
\hline Test & $\chi^{2}$ & $p$-Value & AIC \\
\hline$H_{0}: \rho=0$ & 48.24 & 0 & \\
$H_{0}: \rho+\theta \beta=0$ & 48.20 & 0 & -634.0951 \\
SARAR & & & -651.6453 \\
Durbin & & & \\
\hline
\end{tabular}

The coefficients of the explanatory variables in the non-spatial model are significantly different from zero and have the expected signs. In the SAR version of the model (see Table 4) the results in the coefficients indicate that there is a partial improvement in the quality of public space in those neighborhoods with a higher concentration of tourists, as the indicator of perception of safety is positive and significant (coefficient 0.0027 ), rejected Hypothesis H4a. The previous results are reinforced with Figure 2, which shows that the districts of Madrid with a trend of increasing security perception during the day (years 2015-2018) are the districts with the highest presence of Airbnb accommodations.

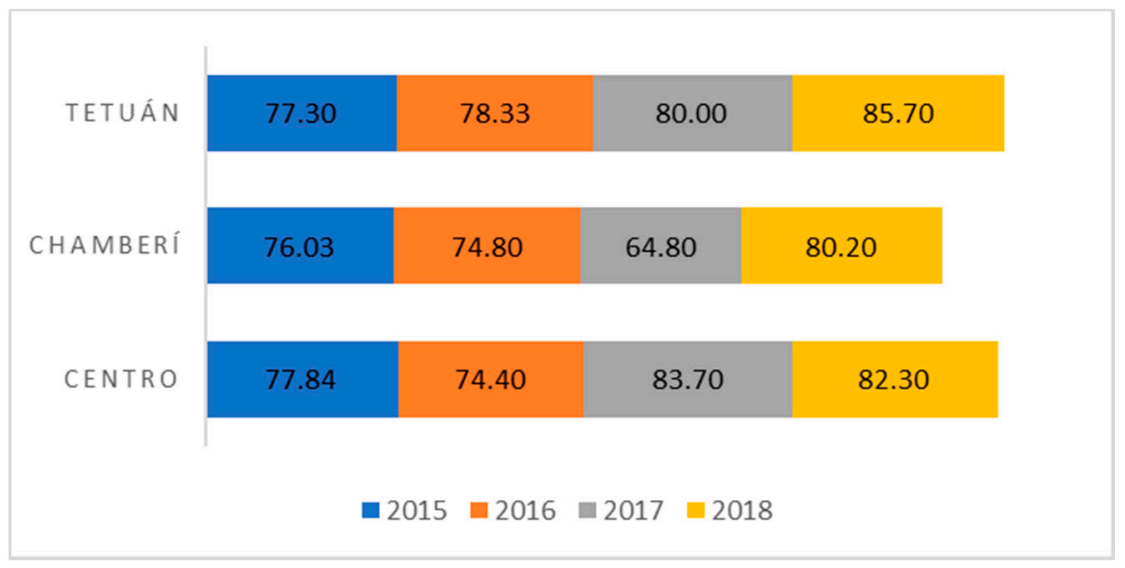

Figure 2. Perception of safety during the day in districts of Madrid with the highest presence of Airbnb accommodations. (Synthetic indicator 0-100).

However, the noise indicator (coefficient 0.008 ), is positive and significant, which indicates a decrease in acoustic comfort. This fact represents a loss in the environmental sustainability of the neighborhoods where there is a greater presence of tourists and that corresponds to a greater number of Airbnb accommodations, H2b. Figures 3 and 4 show the evolution of residents' perception of noise in these neighborhoods. The neighborhood of Embajadores, in the city center district, has experienced the greatest increase in perception of noise, due in large measure to the neighborhood's considerable increase in tourism rental apartments during the research period. In neighborhoods of the Chamberí district, the increase in perception of noise is generalized in all neighborhoods, as in the city center. Chamberí also has two conditions that make environmental impact negative and higher: it has a high rate of Airbnb lodgings, and it is a district that neighbors city center neighborhoods. 


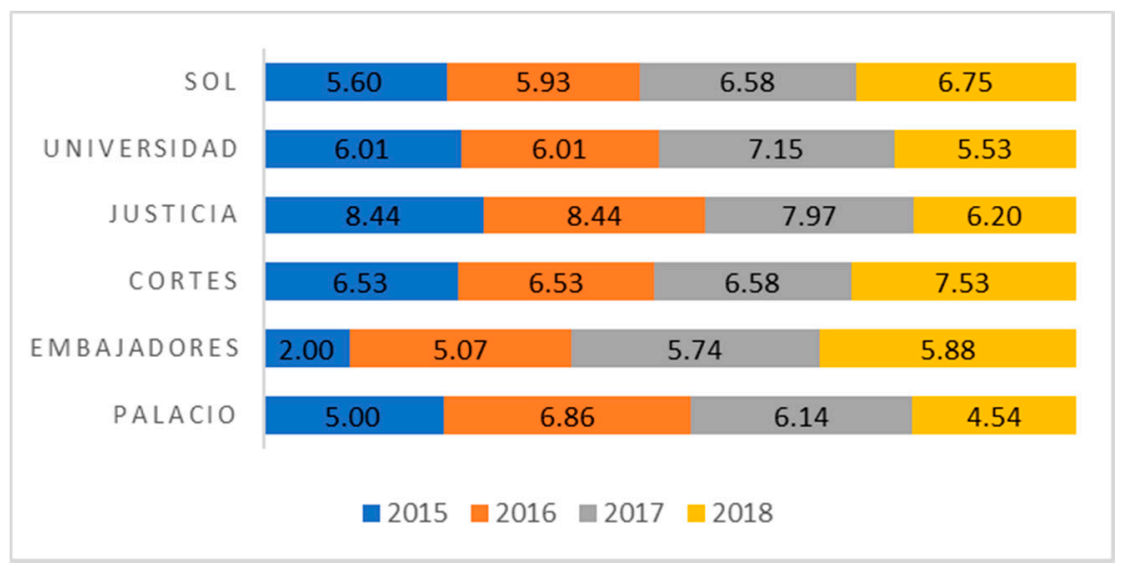

Figure 3. Average perception of noise in neighborhoods of the district of Madrid City Center with the highest presence of Airbnb accommodations (Synthetic indicator 0-10).

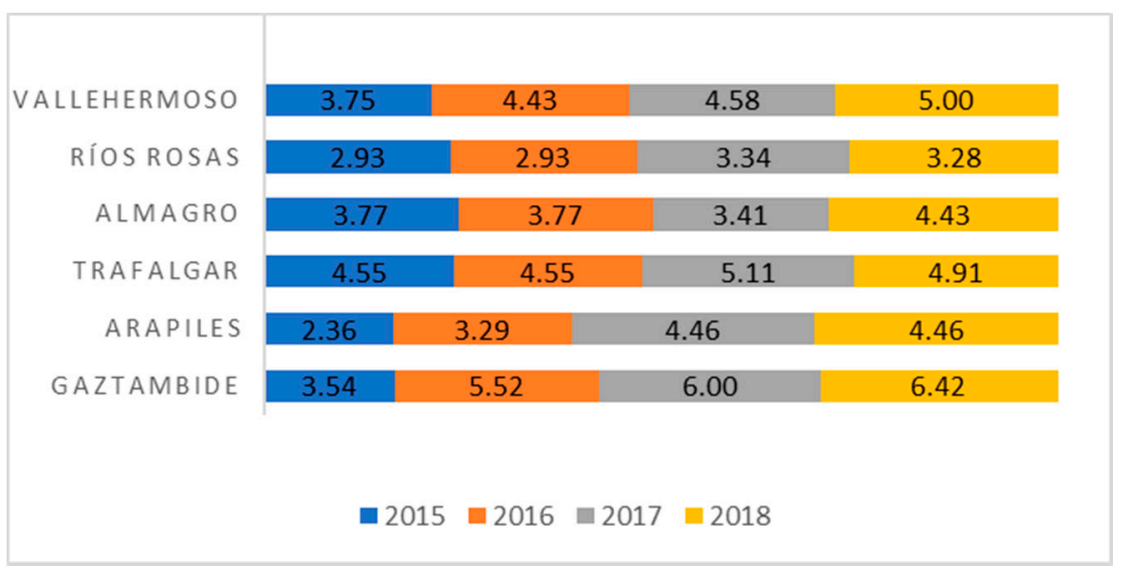

Figure 4. Average perception of noise in neighborhoods of Chamberi district of Madrid with the highest presence of Airbnb accommodations (Synthetic indicator 0-10).

Urban complexity in our model is represented by the indicator of balance of commercial activity (coefficient 0.2209 ). Which, being positive and significant, represents a deterioration due to the dominance of tertiary activities (hotels, restaurants, leisure and shopping centers) versus the activities of the residential population, fulfilling Hypothesis H5a.

The urban metabolism of the neighborhoods with the highest tourist saturation will be reduced because the waste generation indicator (coefficient 0.308 ) is positive and significant as Airbnb accommodations increase according to Hypothesis H2a.

Regarding social and economic issues, the model shows that the neighborhoods in which the aging population increases (coefficient $1.61 \times 10^{-4}$ ) (Hypothesis H1e), with a loss of population under 15 years old, (coefficient -0.1355) (Hypothesis H1f) has a significant and positive increase in income per capita (coefficient 0.0553) (Hypothesis H1c). The interpretation of these three variables together shows the existence of a gentrification process as there is an increase in Airbnb accommodations.

Tourist saturation measured through the Global Index of Tourism Pressure (ISGT) (coefficient 0.002) is positive but not significant. This result leads us to reject the H1d hypothesis. However, this statement cannot be "accepted" in a blunt way; in Figure 5, there is clearly a positive relationship between neighborhoods with a saturation index above the average and the neighborhoods with a greater number of accommodations. The fact that the model accepts the null hypothesis that $H_{0}: \beta_{9}=0$, from the test the individual significance is due to the existence of multicollinearity between the independent variables. One of the consequences of a model having multicollinearity, the correlation 
between the independent variables, is that one or more coefficients are not statistically significant [100]. This is due to the fact that the model presents variances and covariances of the B estimators larger than normal, so the confidence intervals are much wider and favors an easier acceptance of the "null hypothesis 0 " $\left(H_{0}: \beta_{i}=0\right)$. Despite this, the model estimators will continue to be Efficient, Unbiased, and Optimal.

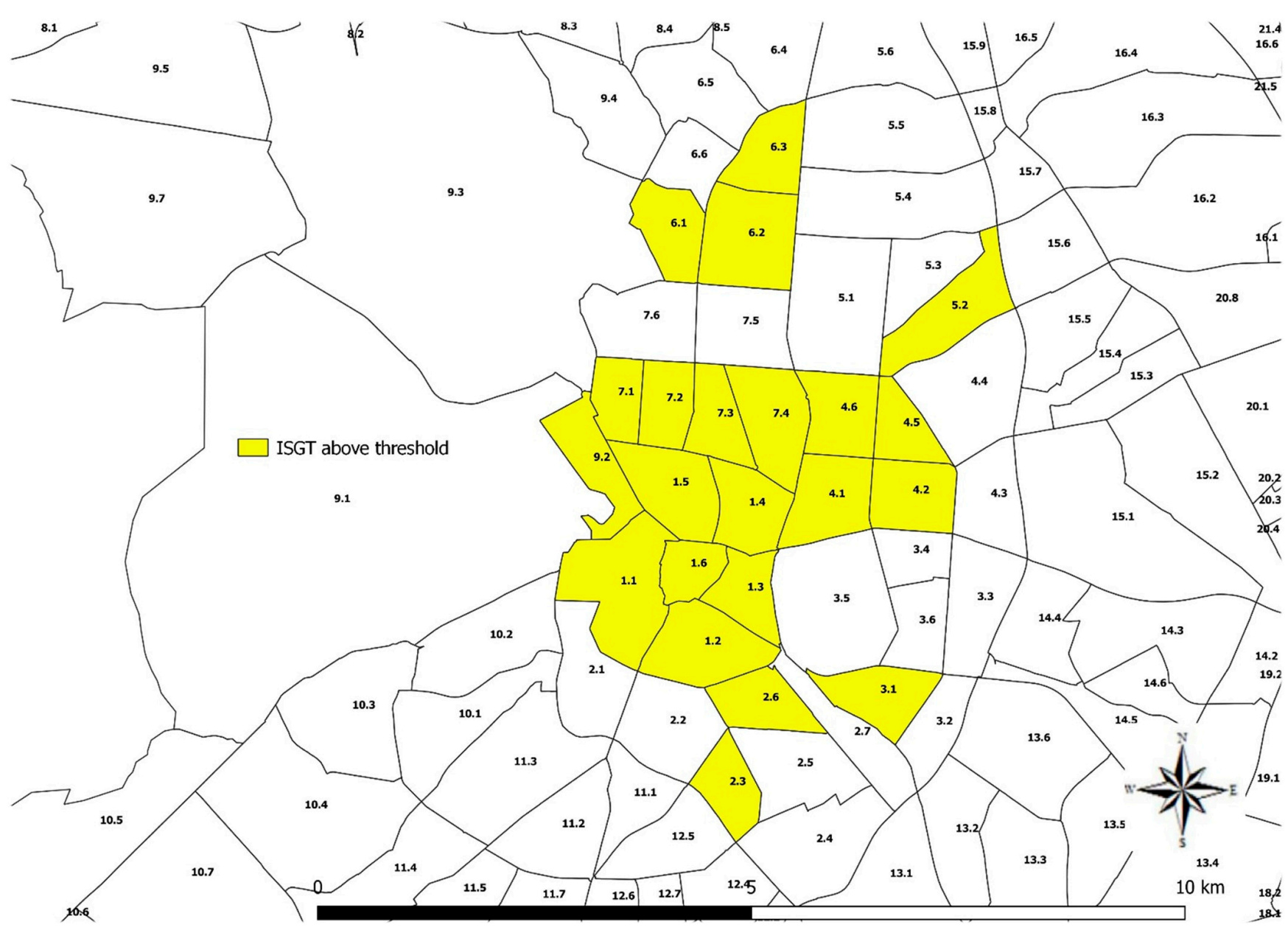

Figure 5. Neighborhoods with ISGT above the threshold with the highest presence of Airbnb accommodations.

Regarding the variables of rent price and purchase-sale price with significant coefficients of 0.0403 and 0.024 , Hypotheses H1a y H1b, respectively, they show that as these prices increase, Airbnb apartments also increase. This finding is confirmed by the rate of income growth of residents in these neighborhoods, which is positive, as shown by evidence in Horn and Merante, [13] the case of Boston. Airbnb supporters argue that sharing one's house allows residents to obtain additional income, enabling some people to continue living in housing markets that appreciate rapidly and to defray other costs of living [13]. These results are also reinforced by Figure 6, where we observe that neighborhoods with the highest rent per square meter are those with the highest density of Airbnb rentals (see Figure 1). Furthermore, Figures 7 and 8 show that the price of housing has increased in neighborhoods in the city center and Chamberí districts-neighborhoods with a high presence of Airbnb. 


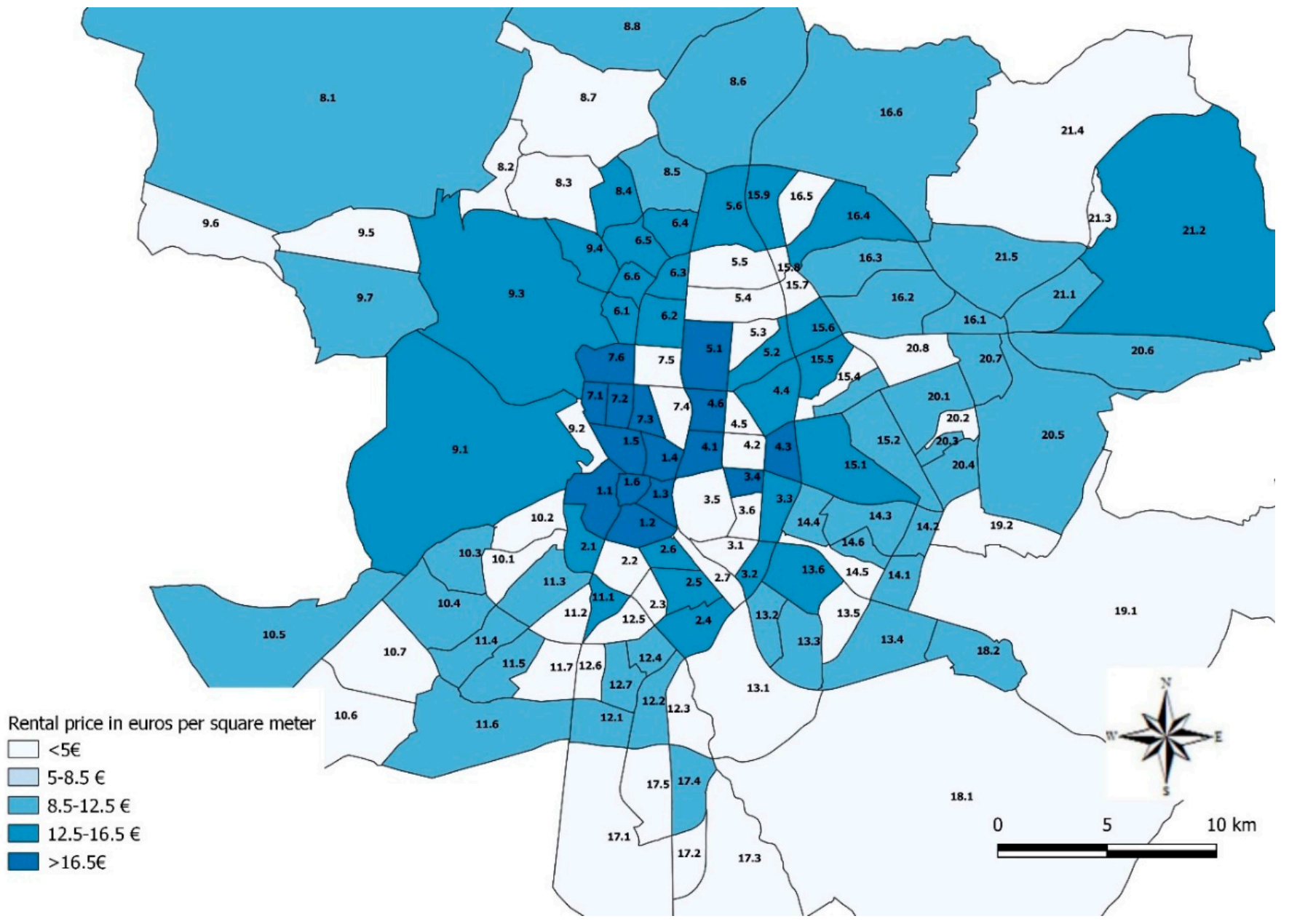

Figure 6. Rental price in euros per square meter in Madrid neighborhoods.

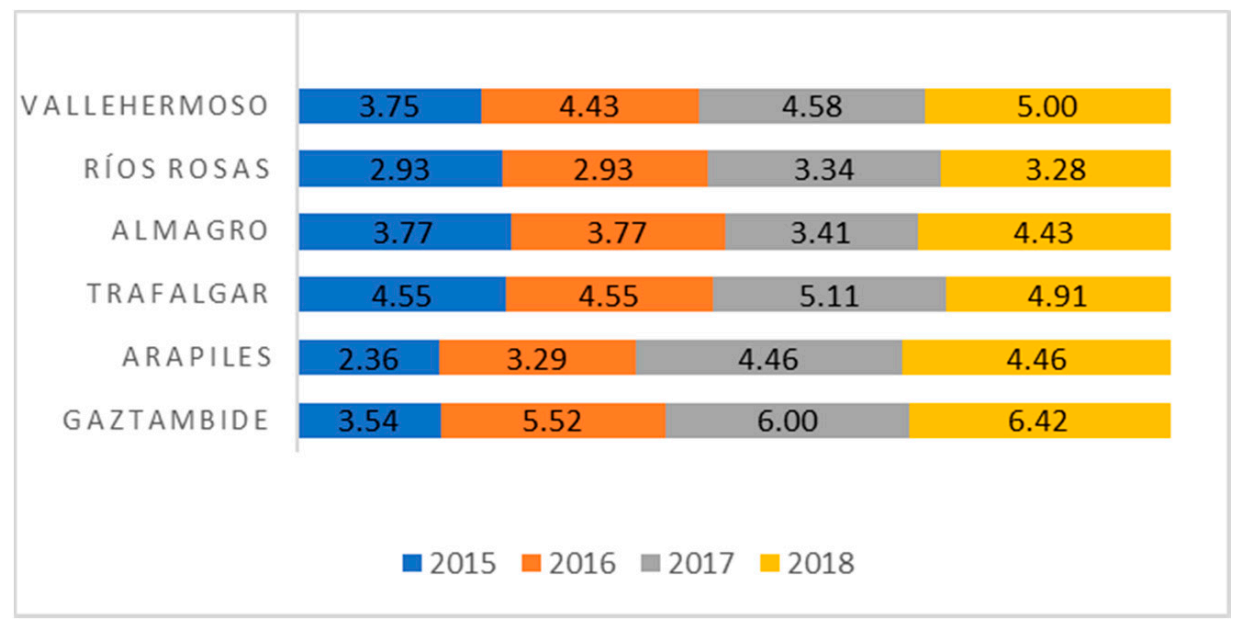

Figure 7. Evolution of price per square meter of housing for neighborhoods of the district of City Center Madrid with the highest presence of Airbnb accommodations (thousands of euros). 


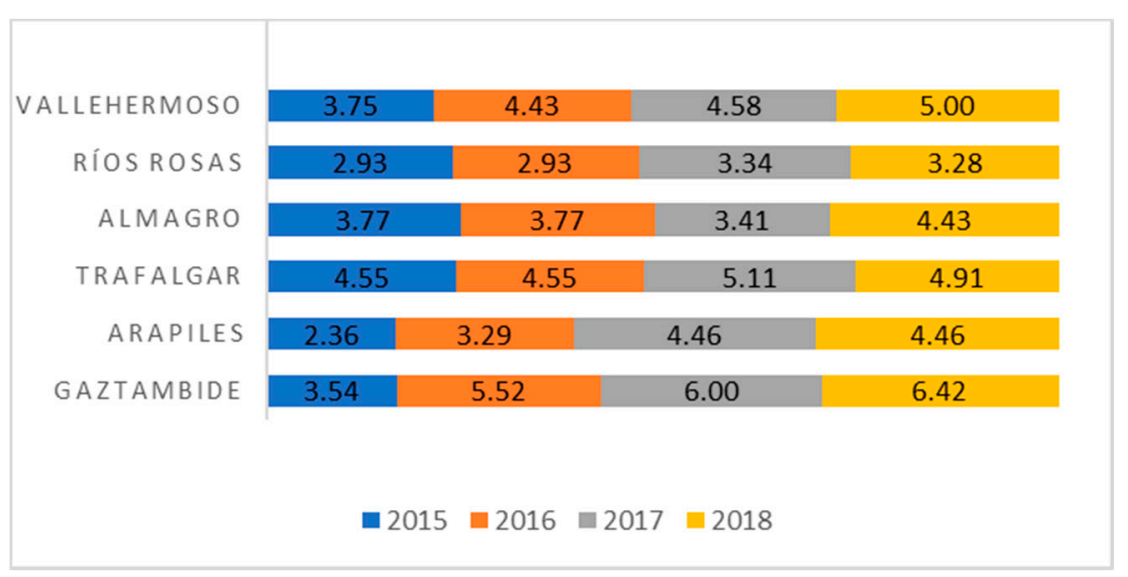

Figure 8. Evolution of price per square meter housing for neighborhoods of the district of Chamberí, Madrid with the highest presence of Airbnb accommodations (thousands of euros).

Theoretical models generally consider the presence of spatial spillover effects that decrease as the distance between spatial units increases. Empirically, spatial panel models have become a popular tool to measure such effects [10].

Elhorst [11] argues, however, that confirming the presence of spatial spillover effects requires determining and comparing the direct and indirect effects generated in spatial models. The direct effects represent the impact on the dependent variable (Airbnb) caused by change in an explanatory variable in a particular location (neighborhood i). On the other hand, the indirect effects can have two meanings, as [101] indicate: 1) the effects of changes in an explanatory variable (neighborhood i) on the dependent variable in other locations (Airbnb in neighborhood j), or 2) the effects of changes in an explanatory variable (neighborhood j) on the dependent variable in location i (Airbnb in neighborhood i).

If a spatial spillover effect of the impact of Airbnb on the city's sustainability exists, it will be seen in the fact that certain effects exist in the neighborhood $j$ (which is adjacent to neighborhood i) due to the stress of tourist apartments and their influence on sustainability of neighborhood i. These effects are reported in Table 7. For [11], the difference between the direct effects of the explanatory variables and their coefficients of estimation is explained by feedback effects from the impacts that pass through their neighbors and return to them.

Table 7 shows that these additional results are consistent in all of the spatial specifications, as the controls are significant and take the expected sign.

We find interesting results when analyzing the direct and indirect effects of the variables:

- The increased perception of safety in the neighborhood " $\mathrm{i}$ " is influenced by the increase in the number of Airbnb apartments in the same neighborhood (0.0028) and in the contiguous neighborhood " $\mathrm{j}$ " (0.011).

- Given that there is a negative relationship, the decrease in the younger population in the neighborhood " $\mathrm{i}$ " increases the total number of Airbnb accommodations in the neighborhood " $\mathrm{i}$ " $(-0.1355)$ and in neighboring neighborhood " $\mathrm{j}$ " $(-0.0509)$, Hypothesis H6a.

- We observe a negative relationship between the elderly population and the number of Airbnb accommodations in neighborhood I and neighborhood j, which leads us to accept Hypothesis H6b.

- The increase in noise and waste production indicators in the neighborhood " $\mathrm{i}$ " causes an increase in the number of accommodations in neighborhood " $j$ ". This means that tourists look for quieter and cleaner adjacent neighborhoods $\mathrm{j}$ in which to stay $(0.0121)$ and $(0.0031)$ when a certain level of noise and waste was reached in " $\mathrm{i}$ ", Hypothesis H6c.

- The increase in housing prices in the neighborhood " $\mathrm{i}$ " (rent and sale) not only motivates the increase in the supply of complete houses in the neighborhood itself $(0.0419$, 
$0.024)$ but also influences neighboring neighborhoods " $j$ " $(0.0156,0.0091)$ that also have an increase in tourist apartments.

- The increase in families with higher average incomes in the neighborhood " $\mathrm{i}$ " will influence the number of Airbnb accommodations to increase in the same neighborhood (0.057), however this increase in prices of real state, causes Airbnb's offer will it to also increase in neighboring neighborhoods " $\mathrm{j}$ " (0.0215).

Table 7. Direct and indirect effects based on estimated coefficients for spatial models reported in Table 3.

\begin{tabular}{|c|c|c|c|}
\hline & SAR & SDM & SAC \\
\hline \multicolumn{4}{|c|}{ Direct effects } \\
\hline Safety_day & $0.0028 * *$ & $-0.0035 *$ & 0.0016 \\
\hline phed & $3.13 \times 10^{-6}$ & $1.15 \times 10^{-5}$ & $5.06 \times 10^{-6}$ \\
\hline logchildr & $-0.1355^{* * *}$ & $-0.1142 * * *$ & $-0.1178^{* * *}$ \\
\hline older & $-1.63 \times 10^{-5 * * *}$ & $1.45 \times 10^{-5 * * *}$ & $-1.46 \times 10^{-5 * * *}$ \\
\hline lemploy & $0.2277^{* * *}$ & $0.1905^{* * *}$ & $0.1996^{* * *}$ \\
\hline Noise & $0.0082 * *$ & 0.0032 & $0.0082 *$ \\
\hline Log_waste & $0.0318^{* * *}$ & $0.0313^{* * *}$ & $0.0328^{* * *}$ \\
\hline Eqact & $0.2255^{* * *}$ & $0.2002 * * *$ & $0.2056^{* * *}$ \\
\hline ISGT & 0.0002 & 0.0004 & $-3.42 \times 10^{-6}$ \\
\hline log_income & $0.0574^{* * *}$ & 0.0262 & $0.0535^{* * *}$ \\
\hline drentl & $0.0419^{* * *}$ & 0.0364 * & $0.0273^{* *}$ \\
\hline pricelag & $0.024^{* *}$ & 0.0166 & $0.0225^{* *}$ \\
\hline \multicolumn{4}{|c|}{ Indirect effects } \\
\hline Safety_day & $0.0011^{* *}$ & 0.0048 * & 0.0013 \\
\hline phed & $1.27 \times 10^{-6}$ & $1.44 \times 10^{-5}$ & $4.26 \times 10^{-6}$ \\
\hline logchildr & $-0.0509^{* * *}$ & $-0.2162 * * *$ & $-0.0932^{* * *}$ \\
\hline older & $-6.15 \times 10^{-6 * * *}$ & $5.29 \times 10^{-6 * * *}$ & $-1.15 \times 10^{-5 * * *}$ \\
\hline lemploy & $0.0857^{* * *}$ & $0.1876^{* * *}$ & $0.1578^{* * *}$ \\
\hline Noise & $0.0031 *$ & $0.0344^{* * *}$ & $0.0065 *$ \\
\hline Log_waste & $0.0121^{* * *}$ & 0.018 & $0.0263^{* * *}$ \\
\hline Eqact & $0.0848^{* * *}$ & 0.1268 & $0.1621^{* * *}$ \\
\hline ISGT & 0.0001 & -0.0004 & $-1.31 \times 10^{-5}$ \\
\hline log_income & $0.0215^{* * *}$ & $0.1281^{* * *}$ & $0.0422 * * *$ \\
\hline drentl & $0.0156^{* * *}$ & -0.025 & $0.0212^{* * *}$ \\
\hline pricelag & $0.0091^{* *}$ & 0.0256 & $0.0178^{* *}$ \\
\hline \multicolumn{4}{|c|}{ Total effects } \\
\hline Safety_day & $0.0039 * *$ & 0.0013 & 0.0029 \\
\hline phed & $4.40 \times 10^{-6}$ & $-2.85 \times 10^{-6}$ & $9.31 \times 10^{-6}$ \\
\hline logchildr & $-0.1864^{* * *}$ & $-0.3304^{* * *}$ & $-0.211^{* * *}$ \\
\hline older & $-2.25 \times 10^{-5 * * *}$ & $-9.25 \times 10^{-6}$ & $-2.61 \times 10^{-5 * * *}$ \\
\hline lemploy & $0.3134^{* * *}$ & $0.3781^{* * *}$ & $0.3574^{* * *}$ \\
\hline Noise & $0.0113 *$ & $0.0376^{* * *}$ & $0.0147 *$ \\
\hline Log_waste & $0.0439 * * *$ & $0.0492^{* * *}$ & $0.0591^{* * *}$ \\
\hline Eqact & $0.3103^{* * *}$ & $0.327^{* * *}$ & $0.3677^{* * *}$ \\
\hline ISGT & 0.0002 & -0.0008 & $-1.65 \times 10^{-5}$ \\
\hline log_income & $0.0789 * * *$ & $0.1542^{* * *}$ & $0.0957^{* * *}$ \\
\hline drentl & $0.0575^{* * *}$ & 0.0114 & $0.0484^{* *}$ \\
\hline pricelag & $0.033 * *$ & $0.0422 *$ & $0.0403^{* *}$ \\
\hline
\end{tabular}


Based on all of the foregoing, we can conclude that spillover effects from the increase in Airbnb exist in the residential neighborhoods of Madrid due to a set of socioeconomic and environmental variables present in the three pillars of sustainable development. Specifically, we demonstrate the presence of global effects and local spatial effects. An increase in Airbnb in adjacent neighborhoods has individual effects on the sustainability of the neighborhood itself, while the same effects are found in the surrounding neighborhoods, although with less impact.

\section{Conclusions and Discussions}

The growth in tourism over recent decades has been accompanied by the concentration of tourism flow towards specific areas, causing overcrowding and problems with carrying capacity and environmental sustainability of main tourism cities in the world. This phenomenon has been identified as "overtourism". Overtourism in turn has contributed to what is known as touristification, which is the term that refers to the impact that tourist overcrowding has on the commercial and social fabric of certain neighborhoods in the world's major tourism cities. These impacts can be identified through the footprint left by tourists on a series of urban sustainability indicators whose evolution will show the transformations suffered by the neighborhoods of tourism cities that suffer from overtourism. However, the impacts of overtourism are increasingly visible in popular areas of cities, which means that even in areas with limited or barely existing tourist activities, residents even can perceive overtourism [102].

In this study, we have tried to explain how all these phenomena determine the location and number of tourist accommodations offered on the Airbnb platform through the footprint left by tourists on the urban sustainability indicators of the neighborhoods of the city of Madrid. To do this, a spatial panel model type SAR was built.

The model allows us to explain the evolution, in terms of number, of Airbnb accommodations in different neighborhoods through a proxy variable of the concept of "overtourism", such as the Global Indicator of Tourism Stress; as well as a series of urban sustainability indicators that reflect the impacts of touristification and the processes of tourism gentrification that local residents endure. This methodology is the best, because only this type of econometric modeling allows us to work on temporal, cross-section and spatial effects at the same time.

Our results show that the demand for tourism housing in certain neighborhoods increases the price of real estate, due to the fact that they support greater tourist saturation and this coincides with a greater number of Airbnb accommodations in those neighborhoods. This fact is a direct consequence of what is known as Airbnbfication, and supports studies by Le Gallo [12], Quattrone [26], and Guttentag [20]. Other consequences of "overtourism" are the indirect repercussions on the sustainability of neighborhoods. One of them is the reduction in the supply of housing for the local population due to the increase in unregulated tourism housing, which has direct implications on the social and economic structure of these neighborhoods, showing that in those neighborhoods where the indicators corresponding to social and economic cohesion worsen, there are a greater number of Airbnb accommodations. These results agree with the definition of Smith [62] and Gothan [103] regarding the concept of gentrification, this conclusion allows us to accept global Hypotheses 1 and 3.

Although the perception of safety in neighborhoods is positive and good in the sense that this indicator improves, in line with the work carried out by Pizam [104] and Lagonigro [37], the noise annoyances and garbage production in neighborhoods because of the greater presence of people are increased, according to the investigations of Dyer [105], Balaban [106], Ahmad [107], which prevents us from fully accepting the global Hypothesis 2.

It has also been found that the neighborhoods where there is a greater number of Airbnb accommodation and greater tourist saturation are more vulnerable in economic, social and environmental aspects, as it happens in mature tourism destinations. This agrees with the study by Almeida [108] and allows us to accept global Hypotheses 1 to 5. At 
last, this research tests Hypothesis 6 regarding the existence of spillover effects in the distribution of Airbnb accommodations. In neighborhoods that reach a certain level of tourist saturation, tourists decide to opt for accommodation in neighboring neighborhoods. This is a new contribution to the existing literature that found a positive relationship between per capita income levels and Airbnb accommodations such as the works of Jiao and Bai [109], Quattrone [19], and Wegman and Jiao [32].

These results demonstrate how the relationship between gentrification and airbnbfication (Hypothesis 1) work together, complementing each other, promoting the transformation of certain neighborhoods where the tourism industry finds benefits, as suggested by the rapid increase in vacation rentals $[5,65]$.

Although our conclusions point to a clear negative relationship between the increase in the number of Airnbnb accommodations and the Urban Sustainability of the neighborhoods that support it, their maximum load capacity has not yet been reached, measured by the ISGT variable. For this reason, and given that the increase in the number of tourists cannot be stopped, those responsible for managing tourism in Madrid should focus on dispersing the concentration of accommodation in the most saturated neighborhoods towards adjacent neighborhoods (spillover effect observed in the research) and in turn try to regulate the growth of entire properties that are dedicated to short-term rental, thus improving the overall sustainability of the city.

Finally, the study opens a new debate on the measures to be taken to improve the sustainability of the city and opens a new way of understanding gentrification processes due to an increase in visitors through urban sustainability indicators. This represents a new contribution to the academic literature on the specific topic of Airbnb, Airbnbfication and sustainability that is very recent and quite limited.

\section{Limitations}

It is very important to keep the limitations of this document in mind. First of all, sustainability is a difficult concept to quantify and interpret, which often depends on the objectives to be achieved. Second, the lack of statistical information at the neighborhood level has not allowed us to study other indicators of urban sustainability that better show the processes of tourism and overtourism. Third, it is possible that there is a causal relationship (to be resolved) between tourist saturation and the number of Airbnb accommodations, which causes certain inefficiencies in the estimated parameters that accompany the explanatory variables of the model. Given the above, this research topic deserves a broader exploration to determine the exact effects of this phenomenon on urban sustainability.

Author Contributions: Conceptualization, A.Á.-H.; methodology, A.Á.-H.; software, E.M.-R.; validation, A.Á.-H..; formal analysis, A.Á.-H. and E.M.-R.; investigation, A.Á.-H. and Edith Macedo; resources, E.M.-R.; data curation, E.M.-R.; writing-original draft preparation, E.M.-R.; writingreview and editing, A.Á.-H.; visualization, A.Á.-H.; supervision, A.Á.-H. Both authors have read and agreed to the published version of the manuscript. All authors have read and agreed to the published version of the manuscript.

Funding: Please add: This research received no external funding.

Institutional Review Board Statement: Not applicable.

Informed Consent Statement: Not applicable.

Data Availability Statement: Data sharing not applicable.

Conflicts of Interest: The authors declare no conflict of interest. 


\section{Appendix A}

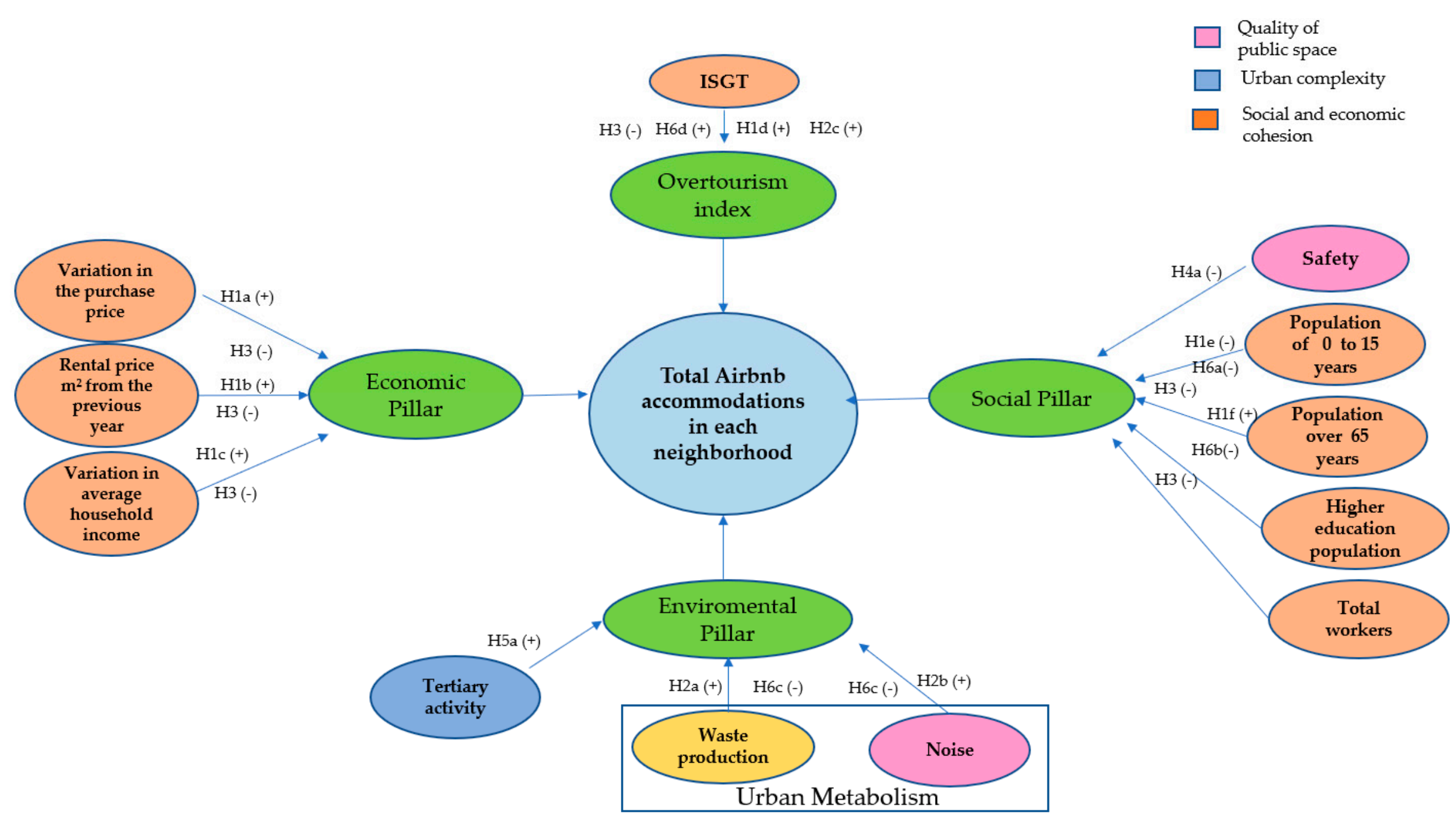

Figure A1. Relationship of hypothesis to the urban sustainability pillars and the number of Airbnb accommodations. 
Table A1. Composition of the neighborhoods of the districts of the city of Madrid in 2018.

\begin{tabular}{|c|c|c|c|c|c|c|}
\hline District Number & Name & District Area hab/ha & Population 2018 & $\begin{array}{l}\text { Population Density and Density of Population } \\
\text { Plus Tourists (hab/ha and hab+Tourists/ha) }\end{array}$ & Location & Administrative Wards \\
\hline 1 & Centro & 522.82 & 132,352 & $253.15 ; 833.58$ & & $\begin{array}{c}\text { 1.1Palacio } \\
\text { 1.2Embajadores } \\
\text { 1.3Cortes } \\
\text { 1.4Justicia } \\
\text { 1.5Universidad } \\
\text { 1.6Sol }\end{array}$ \\
\hline 2 & Arganzuela & 646.22 & 152,907 & $236.62 ; 270.94$ & & $\begin{array}{c}\text { 2.1Imperial } \\
\text { 2.2Las Acacias } \\
\text { 2.3La Chopera } \\
\text { 2.4Legazpi } \\
\text { 2.5Delicias } \\
\text { 2.6Palos de Moguer } \\
\text { 2.7Atocha }\end{array}$ \\
\hline 3 & Retiro & 546.62 & 119,011 & $217.72 ; 263.09$ & & $\begin{array}{c}\text { 3.1Pacífico } \\
\text { 3.2Adelfas } \\
\text { 3.3Estrella } \\
\text { 3.4Ibiza } \\
\text { 3.5Jerónimos } \\
\text { 3.6Niño Jesús }\end{array}$ \\
\hline 4 & Salamanca & 539.24 & 145,268 & $269.39 ; 510.98$ & & $\begin{array}{c}\text { 4.1Recoletos } \\
\text { 4.2Goya } \\
\text { 4.3Fuente del Berro } \\
\text { 4.4Guindalera } \\
\text { 4.5Lista } \\
\text { 4.6Castellana }\end{array}$ \\
\hline
\end{tabular}


Table A1. Cont.

\begin{tabular}{|c|c|c|c|c|c|c|}
\hline District Number & Name & District Area hab/ha & Population 2018 & $\begin{array}{l}\text { Population Density and Density of Population } \\
\text { Plus Tourists (hab/ha and hab+Tourists/ha) }\end{array}$ & Location & Administrative Wards \\
\hline \multirow{6}{*}{5} & \multirow{6}{*}{ Chamartín } & \multirow{6}{*}{917.55} & \multirow{6}{*}{144,894} & \multirow{6}{*}{$157.91 ; 211.04$} & & 5.1El Viso \\
\hline & & & & & & 5.2Prosperidad \\
\hline & & & & & & 5.3Ciudad Jardín \\
\hline & & & & & & 5.4Hispanoamérica \\
\hline & & & & & & 5.5Nueva España \\
\hline & & & & & & 5.6Castilla \\
\hline \multirow{6}{*}{6} & \multirow{6}{*}{ Tetuán } & \multirow{6}{*}{537.47} & \multirow{6}{*}{155,967} & \multirow{6}{*}{$290.19 ; 387.74$} & & 6.1Bellas Vistas \\
\hline & & & & & & 6.2Cuatro Caminos \\
\hline & & & & & & 6.3Castillejos \\
\hline & & & & & & 6.4Almenara \\
\hline & & & & & & 6.5Valdeacederas \\
\hline & & & & & & 6.6Berruguete \\
\hline \multirow{6}{*}{7} & \multirow{6}{*}{ Chamberí } & \multirow{6}{*}{467.92} & \multirow{6}{*}{138,418} & \multirow{6}{*}{$295.82 ; 406.32$} & & 7.1Gaztambide \\
\hline & & & & & & 7.2Arapiles \\
\hline & & & & & & 7.3Trafalgar \\
\hline & & & & & & 7.4Almagro \\
\hline & & & & & & 7.5Ríos Rosas \\
\hline & & & & & & 7.6Vallehermoso \\
\hline \multirow{8}{*}{8} & \multirow{8}{*}{$\begin{array}{c}\text { Fuencarral-El } \\
\text { Pardo }\end{array}$} & \multirow{8}{*}{$23,783.84$} & \multirow{8}{*}{242,928} & \multirow{8}{*}{$10.21 ; 11.13$} & & 8.1El Pardo \\
\hline & & & & & & 8.2Fuentelarreina \\
\hline & & & & & & 8.3Peña Grande \\
\hline & & & & & & 8.4El Pilar \\
\hline & & & & & & 8.5La Paz \\
\hline & & & & & & 8.6Valverde \\
\hline & & & & & & 8.7Mirasierra \\
\hline & & & & & & 8.8El Goloso \\
\hline
\end{tabular}


Table A1. Cont.

\begin{tabular}{|c|c|c|c|c|c|c|}
\hline District Number & Name & District Area hab/ha & Population 2018 & $\begin{array}{l}\text { Population Density and Density of Population } \\
\text { Plus Tourists (hab/ha and hab+Tourists/ha) }\end{array}$ & Location & Administrative Wards \\
\hline 9 & $\begin{array}{l}\text { Moncloa- } \\
\text { Aravaca }\end{array}$ & $4,653.11$ & 117,835 & $25.32 ; 31.07$ & & $\begin{array}{c}\text { 9.1Casa de Campo } \\
\text { 9.2Argüelles } \\
\text { 9.3Ciudad Universitaria } \\
\text { 9.4Valdezarza } \\
\text { 9.5Valdemarín } \\
\text { 9.6El Plantío } \\
\text { 9.7Aravaca }\end{array}$ \\
\hline 10 & Latina & $2,542.72$ & 235,785 & $92.73 ; 92.83$ & & $\begin{array}{c}\text { 10.1Los Cármenes } \\
\text { 10.2Puerta del Ángel } \\
\text { 10.3Lucero } \\
\text { 10.4Aluche } \\
\text { 10.5Campamento } \\
\text { 10.6Cuatro Vientos } \\
\text { 10.7Las Águilas }\end{array}$ \\
\hline 11 & Carabanchel & $1,404.83$ & 248,220 & $176.69 ; 186.41$ & & $\begin{array}{c}\text { 11.1Comillas } \\
\text { 11.2Opañel } \\
\text { 11.3San Isidro } \\
\text { 11.4Vista Alegre } \\
\text { 11.5Puerta Bonita } \\
\text { 11.6Buenavista } \\
\text { 11.7Abrantes }\end{array}$ \\
\hline 12 & Usera & 777.77 & 136,978 & $176.12 ; 178.59$ & & $\begin{array}{c}\text { 12.1Orcasitas } \\
\text { 12.2Orcasur } \\
\text { 12.3San Fermín } \\
\text { 12.4Almendrales } \\
\text { 12.5Moscardó } \\
\text { 12.6Zofío } \\
\text { 12.7Pradolongo }\end{array}$ \\
\hline
\end{tabular}


Table A1. Cont.

\begin{tabular}{|c|c|c|c|c|c|c|}
\hline District Number & Name & District Area hab/ha & Population 2018 & $\begin{array}{l}\text { Population Density and Density of Population } \\
\text { Plus Tourists (hab/ha and hab+Tourists/ha) }\end{array}$ & Location & Administrative Wards \\
\hline \multirow{6}{*}{13} & \multirow{6}{*}{$\begin{array}{l}\text { Puente de } \\
\text { Vallecas }\end{array}$} & \multirow{6}{*}{$1,496.86$} & \multirow{6}{*}{230,488} & \multirow{6}{*}{$153.98 ; 155.43$} & & 13.1Entrevías \\
\hline & & & & & & 13.2San Diego \\
\hline & & & & & & 13.3Palomeras Bajas \\
\hline & & & & & & 13.4Palomeras Sureste \\
\hline & & & & & & 13.5Portazgo \\
\hline & & & & & & 13.6Numancia \\
\hline \multirow{6}{*}{14} & \multirow{6}{*}{ Moratalaz } & \multirow{6}{*}{610.32} & \multirow{6}{*}{94,261} & \multirow{6}{*}{$154.45 ; 154.45$} & & 14.1Pavones \\
\hline & & & & & & 14.2Horcajo \\
\hline & & & & & & 14.3Marroquina \\
\hline & & & & & & 14.4Media Legua \\
\hline & & & & & & 14.5Fontarrón \\
\hline & & & & & & 14.6Vinateros \\
\hline \multirow{8}{*}{15} & \multirow{8}{*}{ Ciudad Lineal } & \multirow{8}{*}{$1,142.57$} & \multirow{8}{*}{214,463} & \multirow{8}{*}{$187.70 ; 201.41$} & & 15.2Pueblo Nuevo \\
\hline & & & & & & 15.3Quintana \\
\hline & & & & & & 15.4Concepción \\
\hline & & & & & & 15.5San Pascual \\
\hline & & & & & & 15.6San Juan Bautista \\
\hline & & & & & & 15.7Colina \\
\hline & & & & & & 15.8Atalaya \\
\hline & & & & & & 15.9Costillares \\
\hline \multirow{6}{*}{16} & \multirow{6}{*}{ Hortaleza } & \multirow{6}{*}{$2,741.98$} & \multirow{6}{*}{183,930} & \multirow{6}{*}{$67.08 ; 72.66$} & & 16.1Palomas \\
\hline & & & & & & 16.2Piovera \\
\hline & & & & & & 16.3Canillas \\
\hline & & & & & & 16.4Pinar del Rey \\
\hline & & & & & & 16.5Apóstol Santiago \\
\hline & & & & & & 16.6Valdefuentes \\
\hline
\end{tabular}


Table A2. Cont.

\begin{tabular}{|c|c|c|c|c|c|c|}
\hline District Number & Name & District Area hab/ha & Population 2018 & $\begin{array}{l}\text { Population Density and Density of Population } \\
\text { Plus Tourists (hab/ha and hab+Tourists/ha) }\end{array}$ & Location & Administrative Wards \\
\hline 17 & Villaverde & $2,018.76$ & 145,523 & $72.09 ; 74.30$ & & $\begin{array}{c}\text { 17.1San Andrés } \\
\text { 17.2San Cristóbal } \\
\text { 17.3Butarque } \\
\text { 17.4Los Rosales } \\
\text { 17.5Los Ángeles }\end{array}$ \\
\hline 18 & Villa de Vallecas & $5,146.72$ & 107,649 & $20.92 ; 25.30$ & & $\begin{array}{c}\text { 18.1Casco Histórico de } \\
\text { Vallecas } \\
\text { 18.2Santa Eugenia } \\
\text { 18.3Ensanche de Vallecas }\end{array}$ \\
\hline 19 & Vicálvaro & $3,526.67$ & 70,962 & $20.12 ; 20.12$ & & $\begin{array}{c}\text { 19.1Casco Histórico de } \\
\text { Vicálvaro } \\
\text { 19.2Valdebernardo } \\
\text { 19.3Valderribas } \\
\text { 19.4El Cañaveral }\end{array}$ \\
\hline 20 & $\begin{array}{c}\text { San } \\
\text { Blas-Canillejas }\end{array}$ & $2,229.24$ & 156,149 & $70.05 ; 94.02$ & & $\begin{array}{l}\text { 20.1Simancas } \\
\text { 20.2Hellín } \\
\text { 20.3Amposta } \\
\text { 20.4Arcos } \\
\text { 20.5Rosas } \\
\text { 20.6Rejas } \\
\text { 20.7Canillejas } \\
\text { 20.8El Salvador }\end{array}$ \\
\hline
\end{tabular}


Table A2. Cont.

\begin{tabular}{|c|c|c|c|c|c|c|}
\hline District Number & Name & District Area hab/ha & Population 2018 & $\begin{array}{l}\text { Population Density and Density of Population } \\
\text { Plus Tourists (hab/ha and hab+Tourists/ha) }\end{array}$ & Location & Administrative Wards \\
\hline \multirow{4}{*}{21} & \multirow{4}{*}{ Barajas } & \multirow{4}{*}{$4,192.28$} & \multirow{4}{*}{47,836} & \multirow{4}{*}{$11.41 ; 25.24$} & & 21.1Alameda de Osuna \\
\hline & & & & & & 21.2Aeropuerto \\
\hline & & & & & & $\begin{array}{l}\text { 21.3Casco Histórico de } \\
\text { Barajas }\end{array}$ \\
\hline & & & & & & 21.4Timón \\
\hline
\end{tabular}




\section{References}

1. Belk, R. You are what you can access: Sharing and collaborative consumption online. J. Bus. Res. 2014, 67, 1595-1600. [CrossRef]

2. Kennedy, J.; Cuddihy, C.; Engel-Yan, J. How traditional firms must compete in the sharing economy. J. Ind. Ecol. 2007, 58, 32-34.

3. Li, J.; Moreno, A.; Zhang, D.J. Agent Behavior in the Sharing Economy: Evidence from Airbnb. SSRN Electron. J. $2015,1298$. [CrossRef]

4. Schäfer, P.; Hirsch, J. Do urban tourism hotspots affect Berlin housing rents? Int. J. Hous. Mark. Anal. 2017, 10, 231-255. [CrossRef]

5. Airbnb, I. Get the Data. Récupéré Sur Inside Airbnb Adding Data to the Debate. Available online: http:/ / insideairbnb (accessed on 1 September 2019).

6. ONU-Hábitat. Urban Indicators Guidelines UN-Habitat. 2004. Available online: https://unhabitat.org/sites/default/files/ download-manager-files/Urban\%20Indicators.pdf (accessed on 15 October 2019).

7. European Commission. Leipzig Charter on Sustainable European Cities; European Commision: Brussels, Belguim, 2007.

8. Milano, C.; Novelli, M.; Cheer, J.M. Overtourism and Tourismphobia: A Journey through Four Decades of Tourism Development, Planning and Local Concerns. Tour. Plan. Dev. 2019, 6, 353-357.

9. Dictionary, Collins. 2015. Available online: https://www.collinsdictionary.com/es / (accessed on 28 December 2020).

10. Belotti, F.; Hughes, G.; Mortari, A.P. Spatial panel data models using Stata Spatial panel data models using Stata. Stata J. 2016, 14, 139-180.

11. Elhorst, J.P. Spatial Panel Models. In Spatial Econometrics From Cross-Sectional Data to Spatial Panels; Springer: Dordrecht, The Netherlands, 2014; pp. 37-94.

12. Ayouba, K.; Breuillé, M.-L.; Grivault, C.; Le Gallo, J. Does Airbnb Disrupt the Private Rental Market? An Empirical Analysis for French Cities. Int. Reg. Sci. Rev. 2020, 43, 76-104. [CrossRef]

13. Horn, K.; Merante, M. Is home sharing driving up rents? Evidence from Airbnb in Boston. J. Hous. Econ. 2017, 38, 14-24. [CrossRef]

14. Sans, A.A.; Quaglieri, A. Unravelling airbnb: Urban perspectives from Barcelona. Reinventing local Tour. Prod. Consum. Negot. Place 2016, 73, 209.

15. Kallis, G. AirBnb is a Rental Economy, Not a Sharing Economy. The press project. 2014. Available online: https://thepressproject. gr/airbnb-is-a-rental-economy-not-a-sharing-economy/ (accessed on 28 December 2020).

16. Ke, Q. Sharing Means Renting?: An Entire-Marketplace Analysis of Airbnb. In Proceedings of the 2017 ACM on Web Science Conference, New York, NY, USA, 25-28 June 2017; pp. 131-139.

17. Lee, D. How Airbnb Short-Term Rentals Exacerbate Los Angeles's Affordable Housing Crisis: Analysis and Policy Recommendations. Harvard Law Policy Rev. 2016, 10, 229-254.

18. Gurran, N.; Phibbs, P. When tourists move in: How should urban planners respond to Airbnb? J. Am. Plan. Assoc. 2017, 83, 80-92. [CrossRef]

19. Quattrone, G.; Proserpio, D.; Quercia, D. Who Benefits from the 'Sharing ' Economy of Airbnb? 2016. Available online: https:/ / www.researchgate.net/publication/301874810_Who_Benefits_from_the_Sharing_Economy_of_Airbnb (accessed on 15 September 2019).

20. Guttentag, D. Airbnb: Disruptive innovation and the rise of an informal tourism accommodation sector. Curr. Issues Tour. 2015, 18, 1192-1217. [CrossRef]

21. Wachsmuth, D.; Weisler, A. Airbnb and the rent gap: Gentrification through the sharing economy. Environ. Plan. A Econ. Space 2018, 50, 1147-1170. [CrossRef]

22. Liang, L.J.; Choi, H.C.; Joppe, M. International Journal of Hospitality Management Exploring the relationship between satisfaction, trust and switching intention, repurchase intention in the context of Airbnb. Int. J. Hosp. Manag. 2018, 69, 41-48. [CrossRef]

23. Airbnb. Fast Facts. 2019. Available online: https://news.airbnb.com/fast-facts/ (accessed on 10 October 2020).

24. Einav, L.; Farronato, C.; Levin, J. Peer-to-Peer Markets. Annu. Rev. Econ. 2016, 8, 615-635. [CrossRef]

25. Udell, A.; Sheppard, S. Estimating the Impact of Airbnb Activity on Housing Prices in New York City. Williams Coll. Honor. Thesis 2016. Available online: https://unbound.williams.edu/theses/islandora/object/studenttheses\%3A64 (accessed on 10 October 2020).

26. Quattrone, G.; Greatorex, A.; Quercia, D.; Capra, L.; Musolesi, M. Analyzing and predicting the spatial penetration of Airbnb in U.S. cities. EPJ Data Sci. 2018, 7, 31. [CrossRef]

27. Achtnicht, M.; Madlener, R. Factors influencing German house owners' preferences on energy retrofits. Energy Policy 2014, 68, 254-263. [CrossRef]

28. IBla, I.; Singal, M.; Templin, J. Airbnb's effect on hotel sales growth. Int. J. Hosp. Manag. 2018, 73, 85-92. [CrossRef]

29. Kakar, V.; Voelz, J.; Wu, J.; Franco, J. The Visible Host: Does Race Guide Airbnb Rental Rates in San Francisco? J. Hous. Econ. 2016, 40, 25-40. [CrossRef]

30. Zervas, G.; Proserpio, D.; Byers, J.W. The Rise of the Sharing Economy: Estimating the Impact of Airbnb on the Hotel Industry. SSRN Electron. J. 2013, LIV, 687-705. [CrossRef]

31. Trinitat, M.; Soto, R.; Clavé, S.A. Land Use Policy Second homes and urban landscape patterns in Mediterranean coastal tourism destinations. Land Use Policy 2017, 68, 117-132. 
32. Wegmann, J.; Jiao, J. Land Use Policy Taming Airbnb: Toward guiding principles for local regulation of urban vacation rentals based on empirical results from five US cities. Land Use Policy 2017, 69, 494-501. [CrossRef]

33. Chasco, C.; Ruiz, S.; Centeno, M.; Vallone, A. El Auge de la Economía Colaborativa en las Ciudades: El Caso de Madrid; ThomsonReuters: Toronto, Canada, 2019; pp. 151-167.

34. Gutiérrez, J.; García-Palomares, J.C.; Romanillos, G.; Salas-Olmedo, M.H. The eruption of Airbnb in tourist cities: Comparing spatial patterns of hotels and peer-to-peer accommodation in Barcelona. Tour. Manag. 2017, 62, 278-291. [CrossRef]

35. Adamiak, C. Mapping Airbnb supply in European cities. Ann. Tour. Res. 2018, 71, 67-71. [CrossRef]

36. Garcia-Ayllon, S. Urban Transformations as an Indicator of Unsustainability in the P2P Mass Tourism Phenomenon: The Airbnb Case in Spain through Three Case Studies. Sustainability 2018, 10, 2933. [CrossRef]

37. Lagonigro, R.; Martori, J.C.; Apparicio, P. Understanding Airbnb spatial distribution in a southern European city: The case of Barcelona. Appl. Geogr. 2020, 115, 102136. [CrossRef]

38. Gravari-Barbas, M.; Guinand, S. Tourism and Gentrification in Contemporary Metropolises: International Perspectives; Taylor \& Francis: Abingdon, UK, 2017.

39. Füller, H.; Michel, B. 'Stop Being a Tourist!' New Dynamics of Urban Tourism in Berlin-Kreuzberg. Int. J. Urban Reg. Res. 2014, 38. [CrossRef]

40. Gravari-Barbas, M.; Delaplace, M. Le tourisme urbain $<<$ hors des sentiers battus $>>$. Coulisses, interstices et nouveaux territoires touristiques urbains. Téoros. Rev. Rech. En Tour. 2015, 34, 1-2.

41. UNWTO. Making Tourism More Sustainable. In A Guide for Policy Makers. 2005. Available online: https://www. sustainablesids.org/knowledgebase/unep-wto-making-tourism-more-sustainable-a-guide-for-policy-makers-2005 (accessed on 1 September 2020).

42. Negruşa, A.L.; Toader, V.; Sofică, A.; Tutunea, M.F.; Rus, R.V. Exploring Gamification Techniques and Applications for Sustainable Tourism. Sustainability 2015, 7, 11160-11189. [CrossRef]

43. Ko, T.G. Development of a tourism sustainability assessment procedure: A conceptual approach. Tour. Manag. 2005, 26, 431-445. [CrossRef]

44. Liu, J.; Nijkamp, P.; Huang, X.; Lin, D. Urban livability and tourism development in China: Analysis of sustainable development by means of spatial panel data. Habitat Int. 2017, 68, 99-107. [CrossRef]

45. Martin, B.S.; Uysal, M. An examination of the relationship between carrying capacity and the tourism lifecycle: Management and policy implications. J. Environ. Manag. 1990, 31, 327-333. [CrossRef]

46. Camagni, R. Sustainable urban development: Definition and reasons for a research programme. Int. J. Environ. Pollut. 1998, 10, 6. [CrossRef]

47. O'Reilly, A.M. Tourism carrying capacity: Concept and issues. Tour. Manag. 1986, 7, 254-258. [CrossRef]

48. UNWTO. Tourism Highlights; 2004 Edition. 2005. Available online: https://www.e-unwto.org/doi/pdf/10.18111/97892844119 00 (accessed on 28 December 2019).

49. Bouchon, F.; Rauscher, M. Cities and tourism, a love and hate story; towards a conceptual framework for urban overtourism management. Int. J. Tour. Cities 2019, 5, 598-619. [CrossRef]

50. Picascia, S.; Romano, A.; Teobaldi, M. The airification of cities. Making sense of the impact of peer to peer short term letting on urban functions and economy. 2019. Available online: https://www.researchgate.net/publication/318707990_The_airification_ of_cities_making_sense_of_the_impact_of_peer_to_peer_short_term_letting_on_urban_functions_and_economy (accessed on 28 December 2019).

51. Alizadeh, T.; Farid, R.; Sarkar, S. Towards understanding the socio-economic patterns of sharing economy in Australia: An investigation of Airbnb listings in Sydney and Melbourne metropolitan regions. Urban Policy Res. 2018, 36, 445-463. [CrossRef]

52. Gant, A.C. Holiday Rentals: The New Gentrification Battlefront. Sociol. Res. Online 2016, 21, 1-9. [CrossRef]

53. Ioannides, D.; Röslmaier, M.; van der Zee, E. Airbnb as an instigator of 'tourism bubble' expansion in Utrecht's Lombok neighbourhood. Tour. Geogr. 2018, 21, 1-19. [CrossRef]

54. Janoschka, M. Gentrificación en España reloaded. Pap. Regió Metrop. Barc. Territ. Estratègies Planejament 2018, 60, $24-33$.

55. Sequera, J.; Nofre, J. Shaken, not stirred: New debates on touristification and the limits of gentrification. City 2018, 22, 843-855. [CrossRef]

56. Jover, J.; Díaz-Parra, I. Gentrification, transnational gentrification and touristification in Seville, Spain. Urban Stud. 2020, 57, 3044-3059. [CrossRef]

57. Hiernaux, D.; González, I. Turismo y gentrificación: Pistas teóricas sobre una articulación. Rev. Geogr. Norte Gd. 2014, 70, 55-70. [CrossRef]

58. López-Gay, A.; Cocola-Gant, A. Cambios demográficos en entornos urbanos bajo presión turística: El caso del barri Gòtic de Barcelona. In Proceedings of the XV Congreso de la Población Española. Población y Territorio en la Encrucijada de las Ciencias Sociales, Fuerteventura, Spain, 8-10 June 2016.

59. Almeida-García, F.; Cortés-Macías, R.; Parzych, K. Tourism Impacts, Tourism-Phobia and Gentrification in Historic Centers: The Cases of M á laga (Spain) and Gdansk (Poland). Sustainability 2021, 13, 408. [CrossRef]

60. López-Gay, A.; Sales-Fava, J. El auge de Airbnb en la Ciudad de México: Implicaciones espaciales y sociodemográficas. Coyunt. Demogáfica 2018, 14. Available online: https:/ / www.researchgate.net/publication/329275346_El_auge_de_Airbnb_en_la_Ciudad_ de_Mexico_implicaciones_espaciales_y_sociodemograficas (accessed on 28 December 2020). 
61. Hof, A.; Schmitt, T. Land Use Policy Urban and tourist land use patterns and water consumption: Evidence from Mallorca, Balearic Islands. Land Use Policy 2011, 28, 792-804. [CrossRef]

62. Smith, N. Toward a theory of gentrification a back to the city movement by capital, not people. J. Am. Plan. Assoc. 1979, 45, 538-548. [CrossRef]

63. Chan, J.H.; Iankova, K.; Zhang, Y.; McDonald, T.; Qi, X. The role of self-gentrification in sustainable tourism: Indigenous entrepreneurship at honghe hani rice terraces world heritage site, China. J. Sustain. Tour. 2016, 24, 1262-1279. [CrossRef]

64. Liang, Z.-X.; Bao, J.-G. Tourism gentrification in Shenzhen, China: Causes and socio-spatial consequences. Tour. Geogr. 2015, 17, 461-481. [CrossRef]

65. Freytag, T.; Bauder, M. Bottom-up touristification and urban transformations in Paris. Tour. Geogr. 2018, 20, 443-460. [CrossRef]

66. Dudás, G.; Vida, G.; Kovalcsik, T.; Boros, L. A socio-economic analysis of Airbnb in New York City. Reg. Stat. 2017, 7, 135-151. [CrossRef]

67. Zhang, Z.; Chen, R.J.C.; Han, L.D.; Yang, L. Key Factors Affecting the Price of Airbnb Listings: A Geographically Weighted Approach. Sustainability 2017, 9, 1635. [CrossRef]

68. Sarkar, A.; Koohikamali, M. Spatial and socioeconomic analysis of host participation in the sharing economy Airbnb in New York City. Inf. Technol. People 2020, 33, 983-1009. [CrossRef]

69. Roelofsen, M.; Minca, C. Geoforum The Superhost. Biopolitics, home and community in the Airbnb dream-world of global hospitality. Geoforum 2018, 91, 170-181. [CrossRef]

70. Yrigoy, I. Airbnb en menorca: ¿Una nueva forma de gentrificación turística?: Localización de la vivienda turística, agentes e impactos sobre el alquiler residencial. Rev. Electrónica Geogr. Y Ciencias Soc. Univ. Barcelona 2017, XXI. [CrossRef]

71. Picard, M. Touristification and Balinization in a Time of Reformasi. Indones. Malay World 2003, 31, 108-118. [CrossRef]

72. Davidson, M.; Lees, L. New-build gentrification: Its histories, trajectories, and critical geographies. Popul. Space Place 2010, 16, 395-411. [CrossRef]

73. Lerario, A.; di Turi, S. Sustainable Urban Tourism: Reflections on the Need for Building-Related Indicators. Sustainability 2018, 10, 1981. [CrossRef]

74. Kennedy, J.; Cuddihy, C.; Engel-Yan, J. The changing metabolism of cities. J. Ind. Ecol. 2007, 11, 43-59. [CrossRef]

75. Sanches, T.L.; Bento, N.V.S. Urban Metabolism: A Tool to Accelerate the Transition to a Circular Economy. In Sustainable Cities and Communities; UNDP: New York, NY, USA, 2020; pp. 860-876.

76. Martín, J.M.M.; Martínez, J.M.G.; Fernadez, J.A.S. An Analysis of the Factors behind the Citizen's Attitude of Rejection towards Tourism in a Context of Overtourism and Economic Dependence on This Activity. Sustainability 2018, 10, 2851. [CrossRef]

77. Stergiou, D.P.; Farmaki, A. Resident perceptions of the impacts of P2P accommodation: Implications for neighbourhoods. Int. J. Hosp. Manag. 2019, 91, 102411. [CrossRef]

78. Agyeiwaah, E. Over-tourism and sustainable consumption of resources through sharing: The role of government. Int. J. Tour. Cities 2019. [CrossRef]

79. Xu, Y.H.; KIM, J.W.; Pennington-Gray, L. Explore the spatial relationship between Airbnb rental and crime. 2017. Available online: https: / / scholarworks.umass.edu/cgi/viewcontent.cgi?article=2075\&context=ttra (accessed on 1 October 2020).

80. Domènech, A.; Larpin, B.; Schegg, R.; Scaglione, M. Disentangling the geographical logic of Airbnb in Switzerland. Erdkunde 2019, 73, 245-258. [CrossRef]

81. Caccese, A. The Airbnb Effect: Architecture and Urban Consequences of a New Way of Trading Homes; Politecnico di Torino: Torino, Italy, 2019.

82. Xu, F.; Hu, M.; La, L.; Wang, J.; Huang, C. The influence of neighbourhood environment on Airbnb: A geographically weighed regression analysis. Tour. Geogr. 2020, 22, 192-209. [CrossRef]

83. Štubňová, M.; Urbaníková, M.; Hudáková, J.; Papcunová, V. Estimation of residential property market price: Comparison of artificial neural networks and hedonic pricing model. Emerg. Sci. J. 2020, 4, 530-538. [CrossRef]

84. Chica-Olmo, J.; González-Morales, J.G.; Zafra-Gómez, J.L. Effects of location on Airbnb apartment pricing in Málaga. Tour. Manag. 2020, 77, 103981. [CrossRef]

85. Tang, L.; Kim, J.; Wang, X. Estimating spatial effects on peer-to-peer accommodation prices: Towards an innovative hedonic model approach. Int. J. Hosp. Manag. 2019, 81, 43-53. [CrossRef]

86. Ferrante, M.; Magno, G.L.L.; de Cantis, S. Measuring tourism seasonality across European countries. Tour. Manag. 2018, 68, 220-235. [CrossRef]

87. Madrid Town Hall Madrid. Tourism Report; Madrid, Spain. 2018. Available online: https://www.madrid-destino.com/sites/ default/files/2019-03/AnuarioTurismoMadrid2018.pdf (accessed on 1 April 2020).

88. Janoschka, M.; Sequera, J.; García;, E. Gentrificación, resistencias y desplazamiento en España. Propuestas analíticas. Gentrificación, Resist. y Desplazamiento en España. Madrid, Contested_Cities. 2014. Available online: http:/ / contested-cities.net/working-papers/ 2014/gentrificacion-resistencias-y-desplazamiento-en-espana-propuestas-analiticas/ (accessed on 1 April 2020).

89. Agencia de Ecología Urbana de Barcelona Plan de Indicadores de Sostenibilidad Urbana. 2010. Available online: https: //repositorio.cepal.org/bitstream/handle/11362/36654/1/S2014040_es.pdf (accessed on 1 October 2020).

90. Unión Europea Reunión informal de Ministros de Desarrollo Urbano. Declaración de Toledo 2010. Pres. Española 2010.es. 2010. Available online: https:/ / ec.europa.eu/regional_policy/archive/newsroom/pdf/201006_toledo_declaration_es.pdf (accessed on 28 December 2020). 
91. Schuschny, A.; Soto, H. Guía Metodológica Diseño de Indicadores Compuestos de Desarrollo Sostenible Andrés Schuschny; Cepal: Santiado de Chile, Chile, 2009.

92. Baltagi, B. Econometric Analysis of Panel Data; John Wiley \& Sons: Hoboken, NJ, USA, 2008.

93. Burridge, P. On the Cliff-Ord Test for Spatial Correlation By. Geogr. Anal. 1980, 4, 267-284. [CrossRef]

94. Anselin, L. Spatial Econometrics: Methods and Models; Springer Science \& Business Media: Berlin, Germany, 1988 ; Volume 4.

95. LeSage, J.; Pace, R.K. Introduction to Spatial Econometrics; Chapman and Hall/CRC: Boca Raton, FL, USA, 2009.

96. Tobler, W.R. A computer movie simulating urban growth in the Detroit region. Econ. Geogr. 1970, 46, 234-240. [CrossRef]

97. Burridge, P. Testing for a common factor in a spatial autoregression model. Environ. Plan. A 1981, 13, 795-800. [CrossRef]

98. Golgher, A.B.; Voss, P.R. How to interpret the coefficients of spatial models: Spillovers, direct and indirect effects. Spat. Demogr. 2016, 4, 175-205. [CrossRef]

99. Vega, S.H.; Elhorst, J.P. On spatial econometric models, spillover effects, and W. In Proceedings of the 53rd ERSA Congress, Palermo, Italy, 27-31 August 2013.

100. Gujarati, D.; Porter, D. Econometría, Quinta Edi.; McGRAW-HILL/Interamericana, Ed. 2010. Available online: https:/ / fvela.files wordpress.com/2012/10/econometria-damodar-n-gujarati-5ta-ed.pdf (accessed on 1 January 2021).

101. Meliciani, V.; Savona, M. The determinants of regional specialisation in business services: Agglomeration economies, vertical linkages and innovation. J. Econ. Geogr. 2015, 15, 387-416. [CrossRef]

102. Koens, K.; Postma, A.; Papp, B. Is overtourism overused? Understanding the impact of tourism in a city context. Sustainability 2018, 10, 4384. [CrossRef]

103. Gotham, K.F. Tourism gentrification: The case of new Orleans' vieux carre (French Quarter). Urban Stud. 2005, 42, 1099-1121. [CrossRef]

104. Milman, A.; Pizam, A. Social impacts of tourism on central Florida. Ann. Tour. Res. 1988, 15, 191-204. [CrossRef]

105. Dyer, P.; Gursoy, D.; Sharma, B.; Carter, J. Structural modeling of resident perceptions of tourism and associated development on the Sunshine Coast, Australia. Tour. Manag. 2007, 28, 409-422. [CrossRef]

106. Balaban, $\mathrm{O}$. The negative effects of construction boom on urban planning and environment in Turkey: Unraveling the role of the public sector. Habitat Int. 2012, 36, 26-35. [CrossRef]

107. Ahmad, F.; Draz, M.; Su, L.; Rauf, A. Taking the bad with the good: The nexus between tourism and environmental degradation in the lower middle-income Southeast Asian economies. J. Clean. Prod. 2019, 233, 1240-1249. [CrossRef]

108. Almeida-García, F.; Cortes-Macías, R.; Balbuena-Vázquez, A.; Carmen-Hidalgo, M. New perspectives of residents' perceptions in a mature seaside destination. Sustainability 2020, 12, 4183. [CrossRef]

109. Jiao, J.; Bai, S. An empirical analysis of Airbnb listings in forty American cities. Cities 2020, 99, 102618. [CrossRef] 